\title{
Changes in the expression of $\alpha$-tocopherol-related genes in liver and mammary gland biopsy specimens of peripartum dairy cows
}

\author{
S. Haga, ${ }^{* 1,2}$ M. Miyaji, $†$ M. Nakano, ${ }^{*}$ H. Ishizaki, ${ }^{*}$ H. Matsuyama, $†$ K. Katoh, $\ddagger$ and S. G. Roh \\ *Grassland Management Research Division, and \\ †Animal Feeding and Management Research Division, Institute of Livestock and Grassland Science, \\ National Agriculture and Food Research Organization (NARO), 768, Senbonmatsu, Nasushiobara, Tochigi, 329-2793, Japan \\ ‡Lab of Animal Physiology, Graduate School of Agriculture Science, Tohoku University, 468-1, Aramaki Aza Aoba, Aoba-ku, Sendai, Miyagi, \\ 980-0845, Japan
}

\section{ABSTRACT}

Blood $\alpha$-tocopherol $(\alpha$-Toc) concentrations decline gradually throughout the prepartum period, reaching the nadir after calving in dairy cows. The $6 \alpha$-Toc-related molecules $[\alpha$-Toc transfer protein (TTPA); afamin; scavenger receptor class B, Type I; ATP-binding cassette transporter A1; tocopherol-associated protein (SEC14L2); and cytochrome P450 family 4, subfamily $\mathrm{F}$, polypeptide $\left.2\left(C Y P_{4} F 2\right)\right]$ are expressed in liver and other peripheral tissues. These molecules could regulate $\alpha$-Toc transport, blood concentrations, and metabolism of $\alpha$-Toc. Therefore, the aim of this study was to evaluate the changes in the expression of $\alpha$-Toc-related genes in liver and mammary gland tissues of dairy cows around calving, which have remained elusive until now. In experiment (Exp.) 1, 28 multiparous Holstein cows were used (from -5 to 6 wk relative to parturition) to monitor the changes in dietary $\alpha$-Toc intake, blood concentrations of $\alpha$-Toc, and lipoproteins; in Exp. 2, 7 peripartum Holstein cows were used (from -4 to 4 wk relative to parturition) for liver tissue biopsy; and in Exp. 3, 10 peripartum Holstein cows were used (from -8 to 6 wk relative to parturition) to carry out the mammary gland tissue biopsy and milk sampling. In Exp. 1, the serum $\alpha$-Toc concentrations declined gradually with decreasing amount of $\alpha$-Toc intake and plasma high-density lipoprotein concentrations toward calving time. However, in the early lactation period after calving, serum $\alpha$-Toc concentrations remained at a lower concentration despite the recovery of $\alpha$-Toc intake and plasma high-density lipoprotein concentrations. In Exp. 2, just after calving, the TTPA, SEC14L2, afamin, and albumin mRNA expression levels in the liver were temporarily downregulated, and the

Received August 4, 2017.

Accepted February 17, 2018.

${ }^{1}$ Corresponding author: hagatiku@affrc.go.jp

${ }^{2}$ Present affiliation: Grazing Animal Unit, Division of Grassland Farming, Institute of Livestock and Grassland Science, NARO. hepatic mRNA levels of endoplasmic reticulum stressinduced unfolded protein response markers and acutephase response marker increased at calving. In Exp. 3, the concentrations of $\alpha$-Toc in colostrum were greater than those in precolostrum (samples were collected at wk -1 relative to parturition) and mature milk. The expression of TTPA, SEC14L2, and CYP4F2 mRNA in bovine mammary gland tissue was detected. However, TTPA and SEC14L2 mRNA expressions showed the opposite trends: the expression levels of TTPA mRNA peaked whereas $S E C 14 L 2$ mRNA reached a nadir at calving. These results indicate that the expression of $\alpha$-Toc-related genes involved in specific $\alpha$-Toc transfer and metabolism in the liver and mammary gland are altered during calving. Moreover, these changes might be associated with the maintenance of lower serum $\alpha$-Toc concentrations after calving.

Key words: $\alpha$-tocopherol deficiency, calving, colostrum production, hepatic function

\section{INTRODUCTION}

In dairy cows, the majority of production diseases occur during early lactation, immediately after calving (Ingvartsen et al., 2003). Therefore, the prevention of these diseases to improve health, welfare, and performance of dairy cows by nutritional and metabolic control is a most important challenge for dairy farms. It is noteworthy that blood $\alpha$-tocopherol $(\boldsymbol{\alpha}$-Toc), the most biologically active form of vitamin $\mathrm{E}$, concentrations decline gradually throughout the prepartum period, reaching the nadir after calving (Goff and Stabel, 1990; Weiss et al., 1990b; Kumagai and Chaipan, 2004). Several studies have documented that lower circulating concentrations of $\alpha$-Toc during peripartum period are strongly associated with the incidence of diseases such as mastitis, retained fetal membranes, and leftdisplaced abomasum (Politis et al., 2012; Qu et al., 2013; Pontes et al., 2015). Therefore, hypovitaminosis E can be an important risk factor for the production 
diseases around calving and warrants further studies to illuminate the underlying causes of $\alpha$-Toc deficiency. Before calving, DMI in dairy cows is depressed, resulting in decreased intake of $\alpha$-Toc from the diet (Weiss et al., 1990a; Meglia et al., 2006). In addition, prepartum supplementation of $\alpha$-Toc $(100$ or $1,000 \mathrm{IU} / \mathrm{d})$ cannot totally prevent a decline in blood $\alpha$-Toc concentrations at calving (Weiss et al., 1997; Meglia et al., 2006). However, little research has been conducted to evaluate in detail the effect of the change in the amount of $\alpha$-Toc intake on the progression of hypovitaminosis $\mathrm{E}$.

Our previous study (Haga et al., 2015) on bovine tissues demonstrated that the liver plays a central role in the regulation of $\alpha$-Toc disposition, as inferred by the high hepatic expression of $6 \alpha$-Toc-related genes, such as afamin (AFM; Voegele et al., 2002); scavenger receptor class B, Type I (SCARB1; Mardones et al., 2002); tocopherol-associated protein (SEC14L2; Yamauchi et al., 2001); $\alpha$-Toc transfer protein (TTPA); ATP-binding cassette transporter A1 (ABCA1); and cytochrome P450 family 4, subfamily F, polypeptide 2 (CYP4F2) (Traber, 2007), which could regulate $\alpha$-Toc transport, blood concentration, tissue distribution, metabolism, and function of $\alpha$-Toc in humans and rodents. In dairy cows, liver function changes substantially around calving, due to (1) stress triggered by the proinflammatory condition associated with parturition and (2) development of fatty liver resulting from the negative energy balance (NEB; Tharwat et al., 2012; Gessner et al., 2014). However, the hepatic expression of $\alpha$-Toc-related genes around calving is still not fully understood. Significant amounts of blood $\alpha$-Toc may be transferred to colostrum (Hidiroglou, 1989; Kumagai and Chaipan, 2004; Calderón et al., 2007). This increased loss of blood $\alpha$-Toc to colostrum might be one of the causes of hypovitaminosis E (Goff et al., 2002), but the molecular mechanism that augments the temporary specific $\alpha$-Toc transfer from the blood to colostrum across the mammary gland at calving is poorly understood. We also reported unique expression patterns of $\alpha$-Toc-related genes and $\alpha$-Toc accumulation properties in bovine nonhepatic peripheral tissues (Haga et al., 2015). However, the expressions of these genes in mammary glands of dairy cows around calving have remained unclear until date.

Therefore, in the present study, we aimed to determine relative mRNA levels of $A F M, S R B 1, S E C 14 L 2$, TTPA, ABCA1, and CYP4F2 in the liver and mammary gland biopsy samples of dairy cows from late pregnancy to early lactation. Our aim was to evaluate the hypothesis that the expression of $\alpha$-Toc-related genes involved in specific $\alpha$-Toc transfer and metabolism in the liver and mammary gland of dairy cows are altered around calving.

\section{MATERIALS AND METHODS}

This study was conducted across 3 animal experiments (Exp.) according to the Guideline for the Institute of Livestock and Grassland Science (NARO, 2011) and approved by the Animal Care Committee of Institute of Livestock and Grassland Science, National Agriculture and Food Research Organization.

\section{Animals and Sample Collection}

Forty-five multiparous Holstein cows were used during the peripartum period in 3 experiments (Exp. 1, 2, and 3). During the experiments, except around calving time, the cows were housed in individual tiestalls (allowed cows to exercise daily in paddock for 1 to $2 \mathrm{~h}$ after the morning feeding) in Exp. 1 and 2 or freestalls in Exp. 3. Cows remained in the calving pen around the time of calving (about -3 to $3 \mathrm{~d}$ relative to parturition); they had free access to fresh water and trace mineral salt blocks (containing per $1 \mathrm{~kg}$ : Fe, 1,232 mg; $\mathrm{Cu}, 150$ mg; Co, 25 mg; Zn, 500 mg; Mn, 500 mg; I, 50 mg; Se, 15 mg; and Na, 382 g; ZENOAQ, Koriyama, Japan). All experimental diets were formulated to meet or exceed the Japanese Feeding Standard for Dairy Cattle (NARO, 2006).

Exp. 1. Twenty-eight multiparous Holstein cows (parity $2.0 \pm 0.8$; means $\pm \mathrm{SE}$ ) were used during the peripartum period ( -5 to 6 wk relative to parturition) to monitor the changes in DMI, the amount of $\alpha$-Toc intake, blood concentrations of $\alpha-T o c$, lipoproteins, and stress markers, milk yield, milk concentrations of $\alpha$-Toc and fat, and calculated $\alpha$-Toc efflux with milk. The cows were offered diets ad libitum (10\% refusals) twice daily (0930 and $1630 \mathrm{~h}$ ) and were milked in their stalls or a milking parlor twice daily (0830 and $1730 \mathrm{~h}$ ). The diets were fed as fermented TMR; their ingredient and chemical compositions are shown in Table 1. The fermented TMR were prepared by wrapping the chopped and shaped whole ingredient mix roll-bale with film and stored until using. The samples of TMR were collected approximately monthly and stored at $-80^{\circ} \mathrm{C}$ until $\alpha$-Toc analysis and at $-30^{\circ} \mathrm{C}$ for determination of the chemical composition (DM, CP, NDF, and ADF). We did not analyze feed refusal. Individual voluntary feed intake was determined daily by calculating the difference between the amounts of feed offered and refused from -3 until 6 wk relative to parturition. Body weight of the cows was measured weekly using a cattle walkover scale. Blood samples were taken from the cows by jugular venipuncture using vacuum tubes containing heparin sodium as an anticoagulant for plasma and not containing an anticoagulant for serum (Terumo Co., Tokyo, Japan) on wk -5 ( -37 to $-29 \mathrm{~d}),-4$ ( -28 to 
$-22 \mathrm{~d}),-3(-21$ to $-15 \mathrm{~d}),-2(-14$ to $-10 \mathrm{~d}),-1$ $(-9$ to $-5 \mathrm{~d}),-0.5(-4$ to $-1 \mathrm{~d}), 0$ (within $12 \mathrm{~h}$ from calving), 0.5 ( 1 to $5 \mathrm{~d}$ ), 1 ( 6 to $11 \mathrm{~d}$ ), 2 (12 to $18 \mathrm{~d}$ ), 3 $(19$ to $25 \mathrm{~d}), 4$ ( 26 to $32 \mathrm{~d}$ ), 5 (33 to $38 \mathrm{~d}$ ), and 6 (39 to $44 \mathrm{~d}$ ) before morning feeding. After sampling, blood samples (heparin tube) for plasma were immediately cooled on crushed ice. For serum collection, sample tubes were kept at $37^{\circ} \mathrm{C}$ for $1 \mathrm{~h}$ in an incubator. After centrifugation $\left(1,000 \times g\right.$ for $20 \mathrm{~min}$ at $\left.4^{\circ} \mathrm{C}\right)$, we stored the plasma and serum at $-30^{\circ} \mathrm{C}$ until analyses. Milk yield was recorded daily from $0 \mathrm{~d}$ until 6 wk relative to parturition. Individual colostrum samples were taken from first milking at $0 \mathrm{~d}$ relative to parturition. Individual milk samples (morning and evening milking combined) were collected at wk 0.5 (transition milk; 2 to $3 \mathrm{~d}$ ), 1 ( 4 to $8 \mathrm{~d}$ ), 2 ( 8 to $11 \mathrm{~d}$ ), 3 (12 to $18 \mathrm{~d}$ ), 4 (19 to $24 \mathrm{~d}), 5(25$ to $31 \mathrm{~d})$, and 6 (32 to $44 \mathrm{~d})$ relative to parturition. Milk fat, lactose, and protein concentrations were analyzed by infrared spectroscopy (Milko-Scan 133B, Foss Electric, Hillerød, Denmark). The whole milk samples were frozen at $-30^{\circ} \mathrm{C}$ until $\alpha$-Toc analysis.

Exp. 2. Seven multiparous Holstein cows (parity 2.9 \pm 0.6 ) were used during peripartum ( -4 to 4 wk relative to parturition) for liver tissue biopsy and blood sampling. The cows were offered diets for ad libitum intake twice daily (0930 and $1630 \mathrm{~h}$ ) and were milked in their stalls or a milking parlor twice daily (0900 and

Table 1. Ingredient and chemical composition of pre- and postpartum fermented TMR in experiment $1^{1}$

\begin{tabular}{|c|c|c|}
\hline Item & Prepartum & Postpartum \\
\hline \multicolumn{3}{|l|}{ Ingredient ( $\%$ of DM) } \\
\hline Rye silage & 63.0 & 16.6 \\
\hline Alfalfa silage & 0.0 & 38.5 \\
\hline Steam-flaked corn or rice & 20.2 & 32.1 \\
\hline Beet pulp & 13.8 & 9.0 \\
\hline Soybean meal & 2.8 & 3.4 \\
\hline Vitamin $\operatorname{mix}^{2}$ & 0.2 & 0.2 \\
\hline Mineral mix ${ }^{3}$ & 0.0 & 0.1 \\
\hline \multicolumn{3}{|l|}{ Chemical composition $^{4}$} \\
\hline $\mathrm{NE}_{\mathrm{L}}^{5}(\mathrm{Mcal} / \mathrm{kg})$ & 1.5 & 1.7 \\
\hline DM $(\%)$ & $37.8 \pm 0.6$ & $53.2 \pm 0.8$ \\
\hline $\mathrm{CP}(\%$ of $\mathrm{DM})$ & $13.6 \pm 0.2$ & $15.6 \pm 0.3$ \\
\hline $\mathrm{NDF}(\%$ of DM) & $48.3 \pm 1.4$ & $35.0 \pm 1.5$ \\
\hline $\mathrm{ADF}(\%$ of $\mathrm{DM})$ & $28.6 \pm 0.7$ & $25.4 \pm 0.4$ \\
\hline$\alpha$-Tocopherol $(\mathrm{mg} / \mathrm{kg}$ of DM) & $97.2 \pm 8.7$ & $90.4 \pm 1.2$ \\
\hline
\end{tabular}

${ }^{1}$ Cow had free access to fresh water and trace mineral salt blocks (containing, per $1 \mathrm{~kg}$ : Fe, 1,232 mg; Cu, $150 \mathrm{mg}$; Co, $25 \mathrm{mg}$; Zn, $500 \mathrm{mg}$; Mn, $500 \mathrm{mg}$; I, $50 \mathrm{mg}$; Se, $15 \mathrm{mg}$; and Na, $382 \mathrm{~g}$ ).

${ }^{2}$ Contained $5,000,000 \mathrm{IU} / \mathrm{kg}$ of vitamin A, $600,000 \mathrm{IU} / \mathrm{kg}$ of vitamin $\mathrm{D}_{3}$, and 20,000 IU/ $\mathrm{kg}$ of DL- $\alpha$-tocopherol acetate. Therefore,

the TMR contained $40 \mathrm{mg}$ of DL- $\alpha$-tocopherol acetate per $\mathrm{kg}$ of DM (1 $\mathrm{IU}$ as equal to $1 \mathrm{mg}$ of DL- $\alpha$-tocopherol acetate).

${ }^{3}$ Contained $220 \mathrm{~g} / \mathrm{kg}$ of $\mathrm{Ca}, 110 \mathrm{~g} / \mathrm{kg}$ of $\mathrm{P}$, and $100 \mathrm{~g} / \mathrm{kg}$ of $\mathrm{Mg}$.

${ }^{4}$ Means \pm SD.

${ }^{5}$ Calculated according to NRC (2001) and NARO (2009).
$1730 \mathrm{~h}$ ). The diets were fed as fermented TMR from the same batch (stock preparation) of roll-bale storage as Exp. 1. In addition, we also used unfermented TMR during the postpartum period, which was based on $26.7 \%$ corn silage, $3.2 \%$ timothy hay, $15.7 \%$ alfalfa hay, $9.8 \%$ beet pulp, $32.7 \%$ steam-flaked corn, $10.0 \%$ soybean meal, $0.4 \%$ vitamin mix, and $1.5 \%$ mineral mix (DM basis). We added the unfermented TMR (about $9.5 \%$ of the total amount of feeding, DM basis) to the fermented TMR in each trough and mixed by hand or shovel just before each feeding. The samples of TMR were collected at 2 times from each pre- and postpartum (total) TMR and stored at $-80^{\circ} \mathrm{C}$ until $\alpha$-Toc and DM analysis (average 74.8 and $82.1 \mathrm{mg}$ of $\alpha-\mathrm{Toc} / \mathrm{kg}$ of DM in pre- and postpartum TMR, respectively). We did not determine the chemical composition (CP, NDF, and ADF) of TMR and did not analyze feed refusal. Individual voluntary feed intake was determined daily by calculating the difference between the amounts of feed offered and refused from -4 until 4 wk relative to parturition. Body weight of the cows was measured weekly using a cattle walk-over scale. Milk yield was recorded daily from $0 \mathrm{~d}$ until $4 \mathrm{wk}$ relative to parturition. Blood and liver biopsy sampling was carried out between 1100 and $1400 \mathrm{~h}$ at wk -4 ( -31 to $-23 \mathrm{~d})$, $-1(-12$ to $-7 \mathrm{~d}), 1$ ( 5 to $7 \mathrm{~d})$, and $4(27$ to $29 \mathrm{~d})$ relative to parturition, and at 0 wk, which was conducted within $12 \mathrm{~h}$ from parturition. Blood samples were taken from the cows by jugular venipuncture using the same materials and method in Exp. 1. Liver tissue was obtained by biopsy as described previously (Miura et al., 1987). Prior to biopsy, the cows were administered an i.m. injection of $2 \%$ lidocaine $(0.05 \mathrm{mg} / \mathrm{kg}$ of BW; $2 \%$ Seractal, Bayer, Leverkusen, Germany) for mild sedation and $5 \%$ tranexamic acid $(2.5 \mathrm{mg} / \mathrm{kg}$ of BW; Vasolamin injection, Meiji-Seika Pharma, Tokyo, Japan) for hemostasis. The biopsy site was selected at the intersection of the right 11 th and 12 th intercostal space and the line from the right point of the acromion to tuber coxae; the area was clipped and scrubbed with 2\% isodine solution (Meiji-Seika Pharma) and $70 \%$ ethanol, and anesthetized by an application of $2 \%$ lidocaine $\mathrm{HCl}$ jelly (2\% Xylocaine jelly, AstraZeneca, London, UK) and an s.c. injection of $3 \mathrm{~mL}$ of $2 \%$ lidocaine $\mathrm{HCl}$ subdermal block (2\% Xylocaine injection, AstraZeneca). A $0.5-\mathrm{cm}$ stab incision was made in the skin and the biopsy was performed using a Bard Magnum Biopsy Gun system with 12-gauge, 10-cm Bard Magnum needles (Bard Biopsy Systems, Tempe, AZ). Pressure was applied to the puncture hole to reduce blood accumulation under the skin immediately after the biopsy, and the spot was disinfected with $10 \%$ isodine gel (Meiji-Seika Pharma). After sampling, a dose of procaine benzylpenicillin antibiotic (Mycillin Sol, 
Meiji-Seika Pharma) or suspension procaine penicillin G injection NZ (ZENOAQ) was administered intramuscularly. The collected samples were rinsed with ice-cold saline solution, immediately frozen in liquid nitrogen, and stored at $-80^{\circ} \mathrm{C}$ until gene expression analysis and triglyceride (TG) analysis.

Exp. 3. Ten multiparous Holstein cows (parity $2.5 \pm$ 0.4 ) were used during peripartum ( -8 to 6 wk relative to parturition) to carry out the mammary gland tissue biopsy, arterial-venous blood, and milk sampling. The cows were offered diets for ad libitum intake twice daily $(0930$ and $1630 \mathrm{~h})$ in prepartum and 3 times (0930, 1500 , and $1800 \mathrm{~h}$ ) in postpartum, and the cows were milked in a milking parlor twice daily (0900 and 1730 h). The diets were the same as those offered to the cows in Exp. 2; we did not measure the $\alpha$-Toc content and chemical composition of TMR nor did we record daily individual voluntary feed intake. Blood samples from the coccygeal artery and milk vein of 5 out of 10 cows were collected to calculate the mammary arterial-venous differences (AVD) and extraction ratio of $\alpha$-Toc as previously described (Thivierge et al., 1998; Astuti et al., 2015) at wk $-8(-57$ to $-46 \mathrm{~d}),-4(-34$ to $-25 \mathrm{~d}),-1$ ( -15 to $-5 \mathrm{~d}$ ), 0 (within $12 \mathrm{~h}$ from calving), 3 ( 23 to $25 \mathrm{~d}$ ), and 6 (38 to $43 \mathrm{~d}$ ) relative to parturition. We also obtained blood samples from the cows by jugular venipuncture to compare with the data of blood $\alpha-T o c$ and metabolites concentrations in Exp. 1 and 2. Mammary gland tissue was obtained by biopsy at wh $-8(-57$ to $-46 \mathrm{~d}),-1$ ( -15 to $-5 \mathrm{~d}), 0$ (within $12 \mathrm{~h}$ from calving), and 6 (38 to $43 \mathrm{~d}$ ) relative to parturition. These samplings were performed between 1300 and $1500 \mathrm{~h}$, except at $0 \mathrm{wk}$, which was conducted within $12 \mathrm{~h}$ of parturition. For arterial blood collection, a needle was inserted into the coccygeal artery located in the middle groove at ventral side of the tail. Blood was collected after confirming the pulse bleeding through the needle. The blood of the left subcutaneous abdominal vein (milk vein) was simultaneously taken from the bottom of the udder. Mammary gland tissue from side to side of the rear quarters was obtained by biopsy, as previously described (Farr et al., 1996). Briefly, cows were administered an i.m. injection of $2 \%$ lidocaine and 5\% tranexamic acid. The quarters were clipped and scrubbed with $2 \%$ isodine solution and $70 \%$ ethanol. The biopsy site was selected at a midpoint of the rear quarter and the area was anesthetized using the same method as that employed in Exp. 2. The mammary biopsy was performed using a Bard Magnum Biopsy Gun system, avoiding any large subcutaneous blood vessels. The collected samples were rinsed with ice-cold saline solution and immediately frozen in liquid nitrogen. Samples were stored at $-80^{\circ} \mathrm{C}$ until gene expression analyses. Pressure was applied to the puncture hole to reduce blood accumulation under the skin immediately after the biopsy, and the spot was disinfected with $10 \%$ isodine gel. After sampling, an i.m. dose of procaine benzylpenicillin antibiotic and Vasolamin was administered, followed by an application of $10 \%$ isodine gel at the biopsy site. Methyl salicylate formulations (Andres ointment, Kyoritsu Seiyaku Co. Ltd., Tokyo, Japan) were applied on the udder at least for $2 \mathrm{~d}$. Cows were machine-milked and hand-stripped to remove intramammary blood clots after sampling at 0 and 6 wh relative to parturition. Cows were hand-stripped as required at each milking for several days until all blood clots were removed and blood contamination was cleared.

Individual milk samples were collected at wk -1 (precolostrum; $-8.7 \pm 2.2 \mathrm{~d}$ ), 0 (colostrum; within $12 \mathrm{~h}$ from calving), $4(25 \mathrm{~d})$, and $6(40 \mathrm{~d})$ relative to parturition. Several aliquots of few milliliters of precolostrum sample were collected by hand-milking. During lactation, colostrum samples from first milking were collected by hand-milking, and mature milk samples were obtained each morning by machine-milking. The samples were frozen at $-30^{\circ} \mathrm{C}$ until $\alpha$-Toc analysis. Milk yield was recorded daily from $0 \mathrm{~d}$ until 6 wk relative to parturition.

\section{Chemical Analysis of TMR}

The TMR samples in Exp. 1 were freeze-dried and ground through a 1-mm screen using a centrifugal mill (ZM200; Retsch \& Co., Haan, Germany). The DM was examined by drying the sample at $105^{\circ} \mathrm{C}$ for $24 \mathrm{~h}$. The Kjeldahl $\mathrm{N}$ were determined by $\mathrm{AOAC}$ International (2000) method 990.03 for $\mathrm{CP}(\mathrm{N} \times 6.25)$. The $\mathrm{NDF}$ and ADF (NDF was assayed with a heat-stable amylase and sodium sulfate, and expressed exclusive of residual ash; ADF was expressed exclusive of residual ash) were analyzed by the methods of Van Soest et al. (1991).

\section{a-Toc Analysis}

All solvents and reagents were HPLC grade and all extractions were performed under dim light. Serum $\alpha$-Toc concentration was measured as described previously (Haga et al., 2014). Milk $\alpha$-Toc was extracted following a protocol described previously (Jensen and Nielsen, 1996). Briefly, each whole milk sample was combined with ascorbic solution, methanol, ethanol, and $60 \% \mathrm{KOH}$, followed by saponification. After adding $n$-hexane, the phases were separated and dried in a centrifugal evaporator (SpeedVac, Thermo Fisher Scientific Inc., Waltham, MA), and the dried residues were resuspended in methanol. The HPLC system and the conditions were the same as those used for the analysis 
of tissue $\alpha$-Toc (Haga et al., 2015). The $\alpha$-Toc contents in the milk were normalized to milk fat weight. The TMR samples (100 $\mathrm{g}$ of fresh matter) were frozen and crushed in liquid nitrogen. Each sample was combined with $1 \% \mathrm{NaCl}, 3 \%$ pyrogallol ethanol, and $60 \% \mathrm{KOH}$. After saponification, $1 \% \mathrm{NaCl}$ and ethyl acetate-hexane $(1: 9, \mathrm{vol} / \mathrm{vol})$ were added to each sample. The organic layer was transferred and dried in a SpeedVac. Methanol was added to dissolve the residue. An HPLC system (1500; Nippon Bunkou Co., Tokyo, Japan) and a $250 \times$ $4.6 \mathrm{~mm}$ C8 column packed with 5 - $\mu \mathrm{m}$ particles (Luna, Phenomenex Inc., Torrance, CA) were used. The mobile phase consisted of methanol and ethanol (9:1, vol/ vol), and fluorescence was detected at an excitation wavelength of $285 \mathrm{~nm}$ and an emission wavelength of $330 \mathrm{~nm}$. The $\alpha$-Toc contents in the TMR were normalized to the DM weight ( $\alpha$-Toc, $\mathrm{mg} / \mathrm{kg}$ of TMR, DM).

\section{Blood Metabolites and Markers Analysis}

Total lipid, HDL, low-density lipoprotein, fatty acids, glucose, and ketone body (combining acetoacetate and BHB) concentrations and aspartate transaminase and $\gamma$-glutamyl transpeptidase activities in plasma were measured with an automatic analyzer (LABOSPECT, Hitachi Ltd., Tokyo, Japan). Plasma cortisol concentrations were measured using a commercial kit (Cortisol ELISA kit, Enzo Life Sciences Inc., Farmingdale, NY). The number of whole blood neutrophils and lymphocytes was counted by a hematology analyzer (XT1800i, Sysmex Corp., Kobe, Japan). Plasma thiobarbituric acid reactive substance (TBARS) concentrations were measured using a commercial kit (TBARS Assay kit, Cayman Chemical, Ann Arbor, MI), and plasma TBARS concentrations were normalized to the plasma total lipid concentrations (TBARS, $\mu \mathrm{mol} / \mathrm{g}$ of total lipid). The TG content in hepatic tissues (wet weight basis) was measured as described previously (Yonezawa et al., 2004).

\section{Total RNA Extraction and cDNA Cloning}

Hepatic and mammary gland biopsy specimens were crushed in liquid nitrogen using a multibead shocker (Yasui Kikai Corp., Tokyo, Japan) and total RNA was isolated using an extraction reagent (TRIzol, Life Technologies Inc., Carlsbad, CA). The absence of RNA degradation was confirmed by electrophoresis in $2 \%$ agarose gel plates. The concentration of total isolated RNA was determined by optical density measurements at $260 \mathrm{~nm}$ and its purity was measured at a wavelength ratio of $260 / 280 \mathrm{~nm}$ (1.8-2.1 was the acceptable value range) using a spectrophotometer (NanoDrop ND1000, Life Technologies Inc.). For cDNA cloning, $1 \mu \mathrm{g}$ of total RNA was reverse transcribed with DNase using a PrimeScript RT reagent Kit with genome DNA Eraser (Takara Bio Inc., Shiga, Japan) according to the manufacturer's instructions (http://www.clontech .com/US/Products/Real-Time_qPCR_and_Reverse _Transcription/Reagents_and_Standards/Two-Step _RT-qPCR/ibcGetAttachment.jsp?cItemId $=56311 \&$ fileId $=7204525 \&$ sitex $=10020: 22372:$ US).

\section{Quantitative Real-Time PCR Analysis}

Quantitative real-time PCR analysis was performed with a PCR reagent (Thunderbird SYBR qPCR Mix, Toyobo Co., Ltd., Osaka, Japan) using a real-time PCR system (StepOnePlus, Life Technologies Inc.). The design of the primers and expected amplicon sizes of the target genes are presented in Supplemental Table S1 (https://doi.org/10.3168/jds.2017-13630). The PCR conditions consisted of 50 cycles of denaturation for $15 \mathrm{~s}$ at $95^{\circ} \mathrm{C}$ and annealing and extension for $1 \mathrm{~min}$ at $60^{\circ} \mathrm{C}$. All primers were tested for PCR suitability by measuring the coefficient of determination values and PCR efficiencies (Supplemental Table S1). Post-PCR melting curves were observed to confirm the specificity of a single-target amplification. Relative mRNA expression was calculated by StepOne Software v2.1 (Life Technologies Inc.) and the $2^{-\Delta \Delta \mathrm{CT}}$ method using arithmetic mean of the ribosomal protein S9 and $\beta$-actin mRNA expressions as multiple housekeeping genes (JanovickGuretzky et al., 2007; Yadav et al., 2012). The values at -4 and -8 wk relative to parturition were set as the reference values in hepatic tissue in Exp. 2 and mammary gland tissue in Exp. 3, respectively.

\section{Calculation and Statistical Analysis}

All analyses were conducted using SAS (Version Add-In 7.1 for Microsoft Office; SAS Institute Japan Ltd., Tokyo, Japan). In Exp. 1, the monitoring data (intake level; blood $\alpha$-toc, HDL, low-density lipoprotein, TBARS, and cortisol concentration; whole blood neutrophil-lymphocyte ratio; milk yield; milk $\alpha$-toc and fat concentrations; and calculated $\alpha$-toc efflux with milk) were analyzed statistically by repeated measures design using the MIXED model procedure with firstorder autoregressive covariance structure $[\mathbf{A R}(\mathbf{1})]$; time (sampling day points or week points), parity $(<3$ or $\geq 3$ ), and the interaction between time and parity were fixed effects, and animal was a random effect. In these data, the effect of parity and the effect of the interaction between time and parity was not significant; therefore, the parity and interaction effects were removed from the model. The effect of time was declared significant at $P<0.05$. To investigate the effect 
of the change of $\alpha$-Toc intake levels on the decreasing serum $\alpha$-Toc concentrations around calving ( -2 to 2 wk), each mean value at -2 wk relative to parturition was set as the reference value (100\%) and compared with the decrease-increase rate between the $\alpha$-Toc intake levels and serum $\alpha$-Toc concentrations at the same time point (no statistical analysis). To investigate the relationship between the change in plasma HDL and serum $\alpha$-Toc concentrations around calving ( -2 to 2 wk), the $\alpha-$ Toc/HDL ratio was analyzed statistically by repeated measures design using the MIXED model procedure with $\mathrm{AR}(1)$ and time (sampling week points) as a fixed effect and animal as a random effect. Upon finding significance of $P<0.05$ for the time, differences among least squares means were analyzed using TukeyKramer tests, with statistical significance at $P<0.05$.

In Exp. 2 and 3, the data (gene expression levels, blood and milk $\alpha$-toc concentrations, blood metabolites concentrations, TG contents in the liver, the value of $\alpha$-toc AVD, and extraction ratio) were analyzed statistically by repeated measures design using the MIXED model procedure with $\mathrm{AR}(1)$ and time (sampling week points) as fixed effects and animal as a random effect. Upon finding significance of $P<0.05$ for the time, differences among least squares means were analyzed using Tukey-Kramer tests, with statistical significance at $P<0.05$. We could not include the effect of parity in the statistical analysis because we used inadequate number of cows in Exp. 2 and 3.

\section{RESULTS}

\section{Relationship Between Changes in a-Toc Intake and Serum $\alpha$-Toc Concentrations (Exp. 1)}

The changes in DMI and $\alpha$-Toc intake throughout the Exp. 1 are presented in Figure 1A and B. The levels of DMI and $\alpha$-Toc intake changed significantly with time $(P<0.01)$. The $\alpha$-Toc contents were not significantly different between pre- and postpartum TMR (Table 1). In the close-up period, the $\alpha$-Toc intake gradually decreased and cows suffered a decline in $\alpha$-Toc intake at calving. The NRC (2001) recommendation for amount of total $\alpha$-Toc is approximately $2.0 \mathrm{mg} / \mathrm{kg}$ of BW $(2.6$ $\mathrm{IU} / \mathrm{kg}$ of $\mathrm{BW} ; 0.8 \mathrm{IU} / \mathrm{kg}$ of BW supplemental $\alpha-\mathrm{Toc}$ plus $1.8 \mathrm{IU} / \mathrm{kg}$ of $\mathrm{BW} \alpha$-Toc provided by feedstuffs) during late gestation and for lactating dairy cows. In Exp. 1, the amount of $\alpha$-Toc intake during -3 wk to $5 \mathrm{~d}$ relative to parturition was less than $2.0 \mathrm{mg} / \mathrm{kg}$ of BW. After calving, DMI and $\alpha$-Toc intake progressively recovered and increased with time. We observed the time effect $(P<0.01)$ on the changes in serum $\alpha$-Toc concentrations (Figure 1C). The serum concentrations of $\alpha$-Toc decreased during the close-up period, reaching a nadir after parturition until $0.5 \mathrm{wk}$ relative to parturition. The comparison of the changes in $\alpha$-Toc intake levels and serum $\alpha$-Toc concentrations around calving period ( -2 to 2 wk relative to parturition, Figure 1D) revealed that, in the first week of lactation, $\alpha$-Toc intake rate increased over $100 \%$ whereas serum $\alpha$-Toc concentrations remained under $80 \%$ of the values at -2 wk relative to parturition.

\section{Relationship Between Changes in Blood HDL and $\alpha$-Toc Concentrations (Exp. 1)}

We observed the time effect $(P<0.01)$ on the changes of plasma HDL and low-density lipoprotein concentrations during the peripartum period (Figure 2A). The concentrations of HDL, a major lipoprotein in cows, gradually decreased toward the time of calving. After parturition, the concentrations progressively recovered and increased with time. The $\alpha$-Toc/HDL ratio, which assesses the rate-limiting levels of HDL concentration as an $\alpha$-Toc carrier, was significantly lower $(P<0.05)$ during the postcalving than during the precalving period; it dropped by $39.7 \%$, reaching a nadir level at 0.5 wk relative to parturition, as compared with that in -2 wk relative to parturition (Figure 2B).

\section{Changes in Milk a-Toc Concentrations and Calculated $\alpha$-Toc Efflux from Mammary Gland (Exp. 1)}

Between 0 and $7 \mathrm{~d}$ relative to parturition, milk yield rapidly increased $(P<0.05)$, exceeding $40 \mathrm{~kg} / \mathrm{d}$ at 20 $\mathrm{d}$ relative to parturition (Figure $3 \mathrm{~A}$ ). In contrast, milk $\alpha$-Toc concentration (Figure $3 \mathrm{~B}$ ) and the amount of daily $\alpha$-Toc efflux with milk (concentration $\times$ milk yield, Figure $3 \mathrm{C})$ were highest in colostrum $(0 \mathrm{~d}$ relative to parturition) and declined $(P<0.05)$ in transition milk (2-3 d relative to parturition), reaching nadir levels in mature milk after 1 wk relative to parturition. The data of mean milk fat levels are shown in Supplemental Figure S1 (https://doi.org/10.3168/jds.2017 -13630).

\section{Changes in Levels of Oxidative and Physiological Stress Markers (Exp. 1)}

The changes in the concentration of plasma TBARS used as an oxidative marker are shown in Figure 4A. We observed the time effect $(P<0.01)$ on the changes of plasma TBARS concentrations during the peripartum period. Their level at calving was highest during the peripartum period. The changes in physiological stress 
A

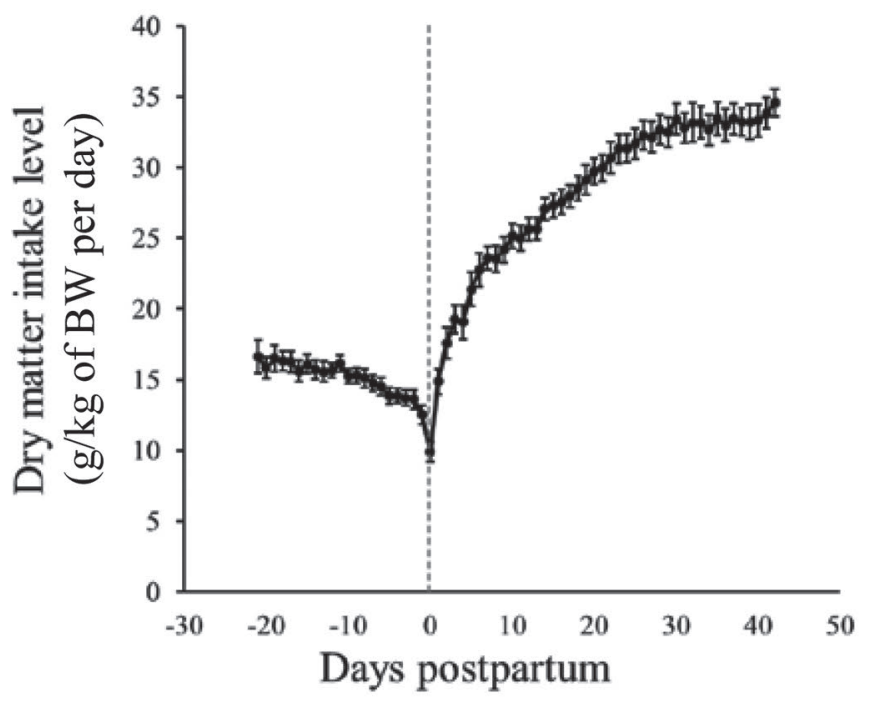

C

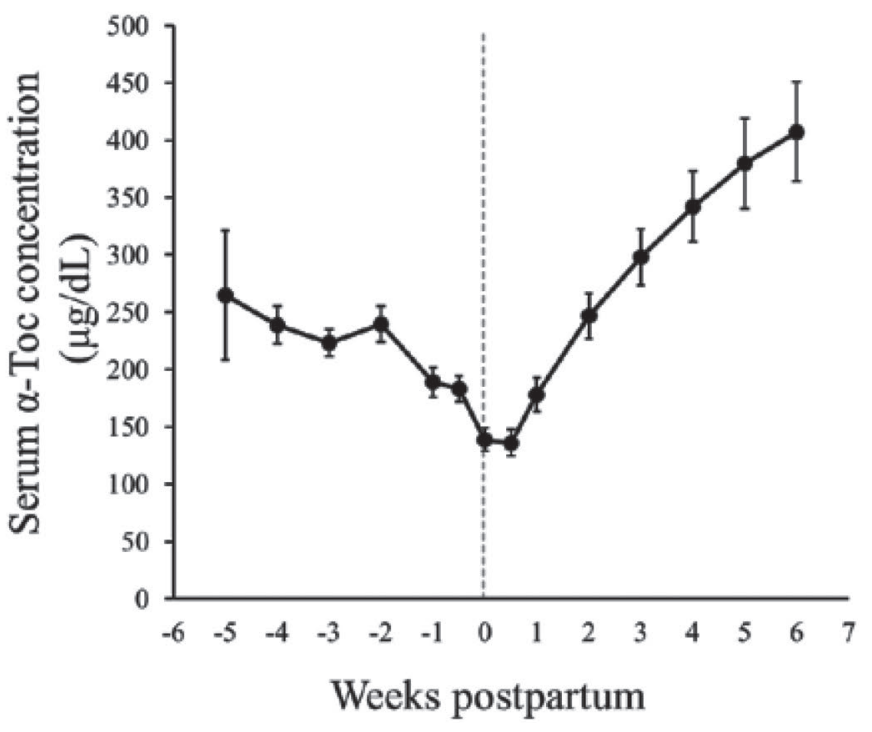

B

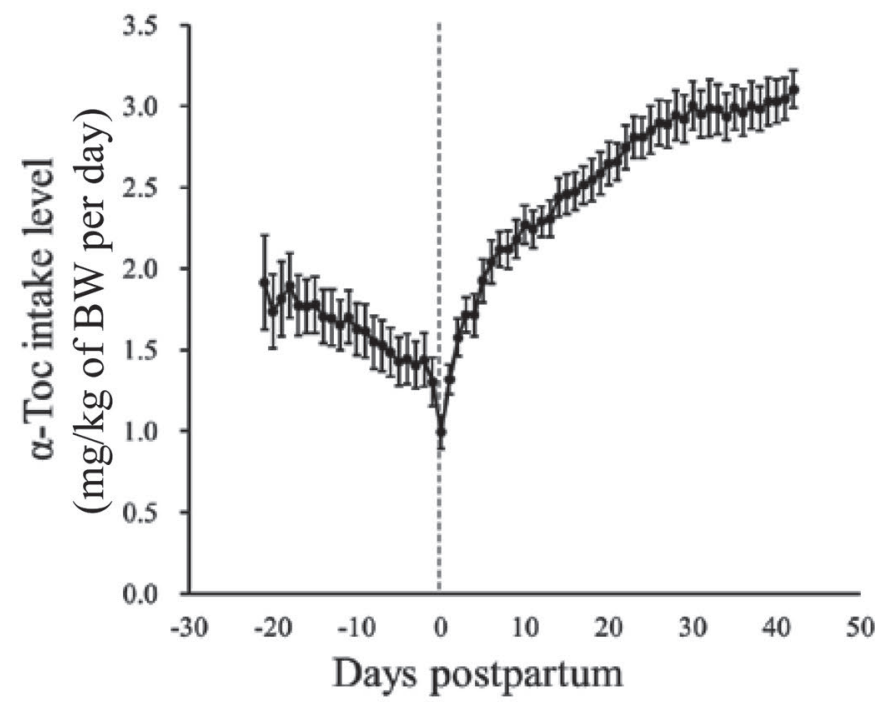

D

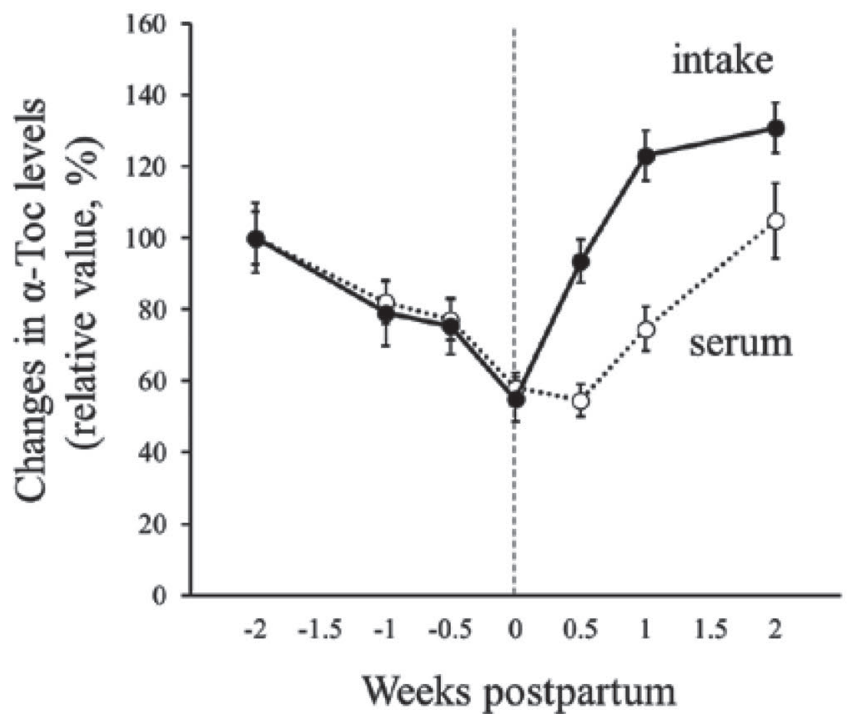

Figure 1. Relationship between the intake levels and serum concentrations of $\alpha$-tocopherol ( $\alpha$-Toc) in peripartum dairy cows. Changes in (A) DMI, (B) $\alpha$-Toc intake levels, and (C) serum $\alpha$-Toc concentrations in peripartum dairy cows. In each data set, an effect of time (i.e., sampling day points or week points) was observed $(P<0.01)$. (D) Collation of the changes in $\alpha$-Toc intake levels and serum $\alpha$-Toc concentrations around calving ( -2 to $2 \mathrm{wk})$ in dairy cows. To investigate the effect of the change of $\alpha$-Toc intake levels on the decreasing serum $\alpha$-Toc concentrations around calving ( -2 to $2 \mathrm{wk}$ ), each mean value at -2 wk relative to parturition( $\alpha$-Toc intake level was $1.8 \mathrm{mg} / \mathrm{kg}$ of BW and serum $\alpha$-Toc concentration was $239.5 \mu \mathrm{g} / \mathrm{dL}$ ) was set as the reference value (100\%) and compared with the decrease-increase rate between the $\alpha$-Toc intake levels and serum $\alpha$-Toc concentrations at the same time point. All data are expressed as means \pm SE ( $\mathrm{n}=28$, no statistical analysis).

markers, plasma cortisol concentration, and the whole blood neutrophil-to-lymphocyte ratio are presented in Figure 4B and $\mathrm{C}$, and we confirmed the effect of time $(P<0.01)$ on the changes in both the markers. At calving, plasma cortisol rapidly increased and then decreased within several days after calving. In the closeup period, the blood neutrophil-to-lymphocyte ratio gradually increased and peaked at calving.

\section{Changes in Hepatic a-Toc-Related Gene Expression and Metabolic Parameters (Exp. 2)}

The changes in the expression of $\alpha$-Toc-related genes in hepatic tissues are shown in Figure 5A. Just after calving, the TTPA, SEC14L2, and AFM mRNA expression levels were temporarily downregulated significantly lower $(P<0.05)$ than those at $1 \mathrm{wk}$ relative to parturi- 
A

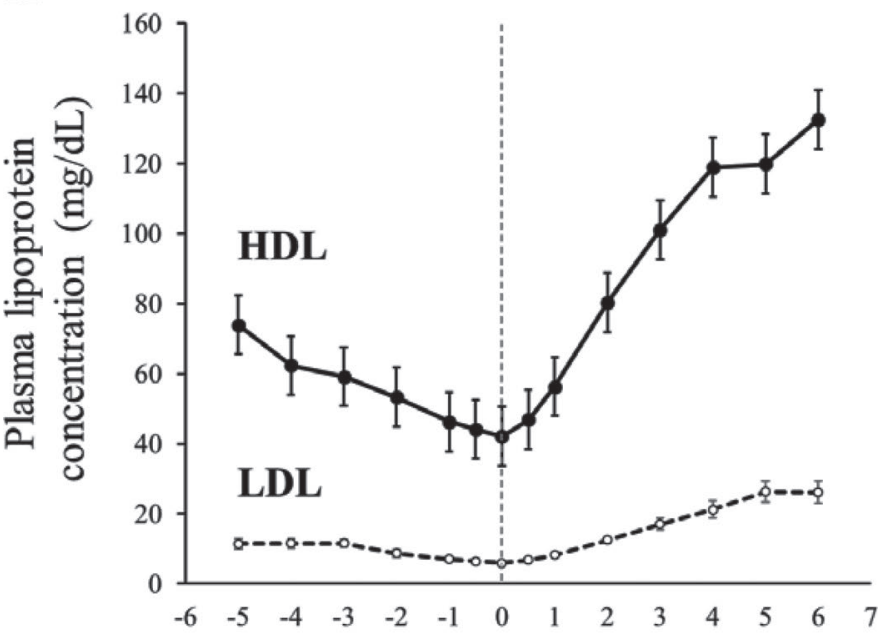

B

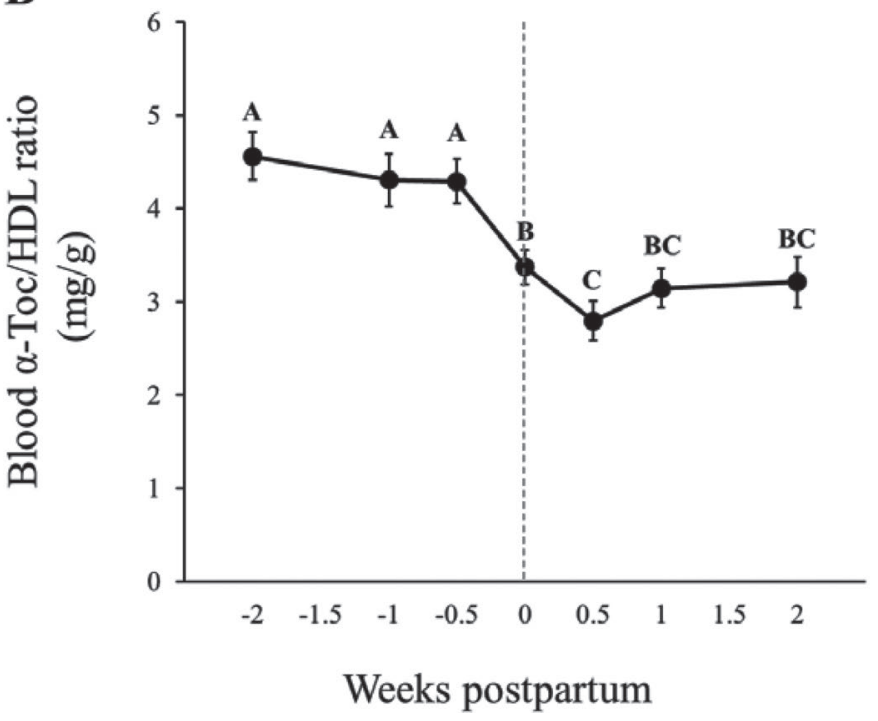

Figure 2. Relationship between blood high-density lipoprotein (HDL) and $\alpha$-tocopherol ( $\alpha$-Toc) concentrations in dairy cows. (A) Plasma HDL (solid line) and low-density lipoprotein (LDL, dotted line) concentrations in peripartum dairy cows. In both data sets, an effect of time (i.e., sampling week points) was observed $(P<0.01)$. (B) Changes in blood $\alpha$-Toc/HDL ratio, which assesses the rate-limiting levels of HDL concentration as an $\alpha$-Toc carrier, around calving ( -2 to 2 wk) in dairy cows. Different capital letters $(\mathrm{A}-\mathrm{C})$ indicate significant difference according to Tukey-Kramer test $(P<0.05)$. All data are expressed as means $\pm \mathrm{SE}(\mathrm{n}=28)$.

tion; the $A B C A 1$ mRNA was temporarily upregulated $(P<0.05)$ as compared with the levels at $-4,1$, and 4 wk relative to parturition. The mRNA expression levels of $C Y P 4 F 2$ and $S R B 1$ in the first week postpartum were significantly higher $(P<0.05)$ compared with those at other times. The hepatic mRNA expression of albumin, superoxide dismutase- 1 , and catalase mRNA at $0 \mathrm{wk}$ relative to parturition was temporarily downregulated $(P<0.05$, Figure 5B), similar to TTPA, SEC14L2, and
A
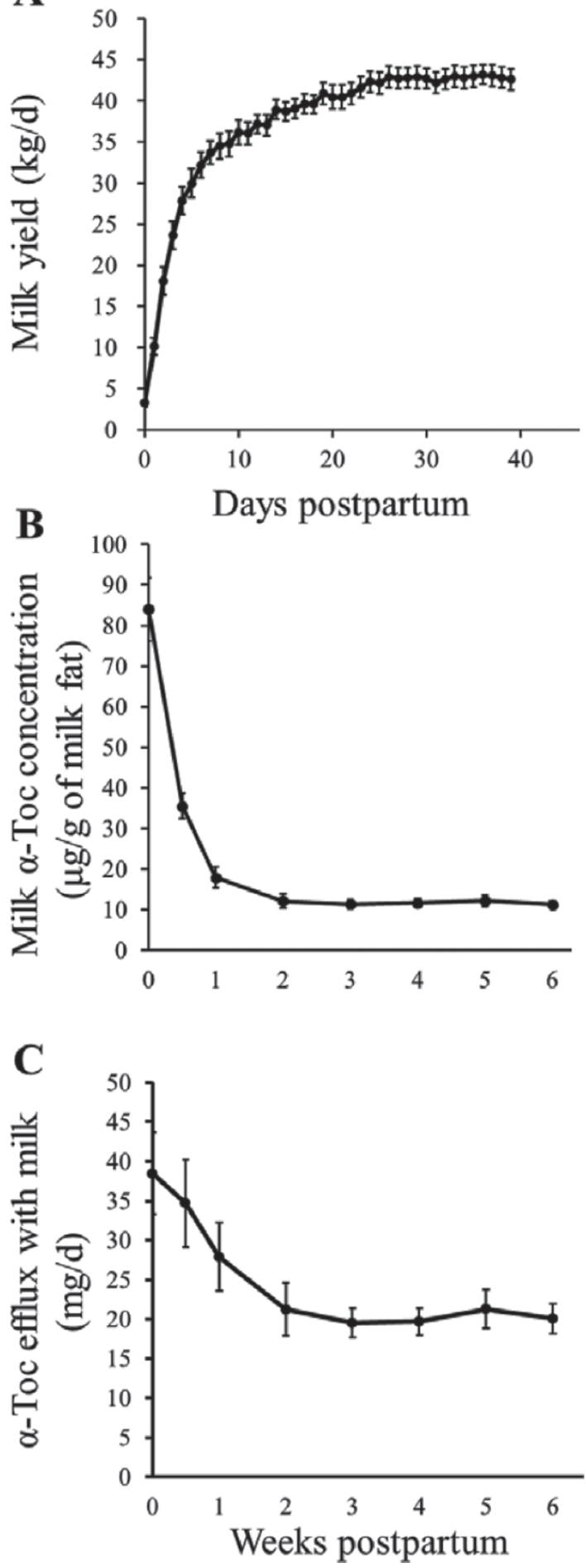

Figure 3. Changes in milk $\alpha$-tocopherol ( $\alpha$-Toc) concentrations and calculated $\alpha$-Toc efflux from mammary gland. (A) Milk yield, (B) $\alpha$-Toc concentrations in milk, and (C) calculated daily $\alpha$-Toc efflux from mammary gland (concentration $\times$ milk yield) in peripartum dairy cows. In each data set, an effect of time (sampling day points or week points) was observed $(P<0.01)$. All data are expressed as means $\pm \mathrm{SE}(\mathrm{n}=28)$. The $\alpha$-Toc concentrations in the milk were normalized to milk fat weight. The data of milk fat concentrations are shown in Supplemental Figure S1 (https://doi.org/10.3168/jds.2017-13630). 
A
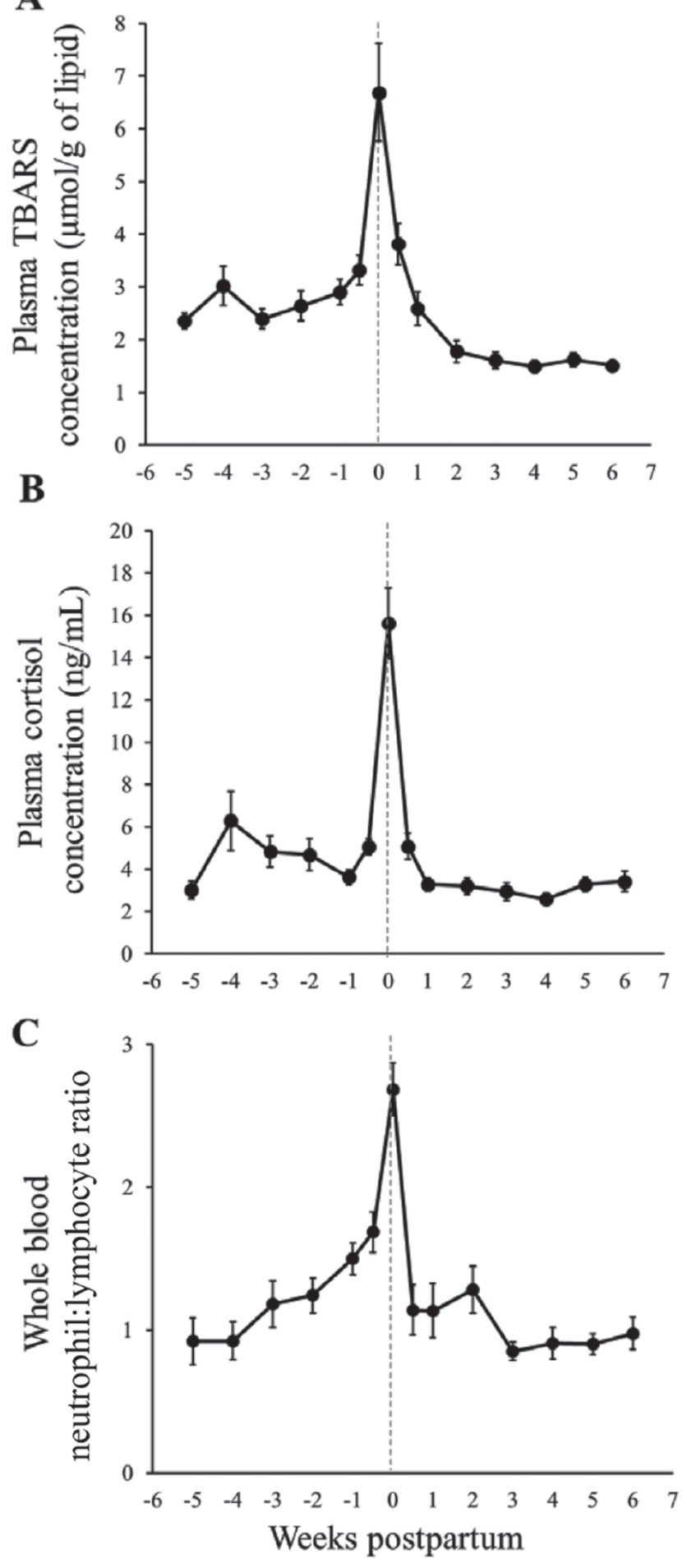

Figure 4. Changes in the levels of oxidative and physiological stress markers. (A) Plasma concentration of thiobarbituric acid reactive substance (TBARS) as an oxidative stress marker in peripartum dairy cows. The concentrations were normalized to the plasma total lipid concentrations (TBARS, $\mu \mathrm{mol} / \mathrm{g}$ of total lipid). (B) Plasma cortisol concentrations and (C) whole blood neutrophil:lymphocyte ratio as physiological stress markers. In each data set, an effect of time (sampling week points) was observed $(P<0.01)$. All data are expressed as means \pm SE $(\mathrm{n}=28)$.
AFM mRNA. The mRNA levels of the spliced form of $\mathrm{X}$-box binding protein 1 and $\mathrm{C} / \mathrm{EBP}$-homologous protein 10, 2 endoplasmic reticulum (ER) stress-induced unfolded protein response (UPR) markers in the liver, sharply increased $(P<0.05)$ at calving (Figure 5B). Furthermore, haptoglobin mRNA dramatically increased $(P<0.05)$, peaked at parturition, and then gradually decreased, but in the first week postpartum it remained about 10 times higher compared with that at 4 wk relative to parturition (Figure 5B).

Changes in serum $\alpha$-Toc and metabolic parameters concentrations in Exp. 2 were shown in Table 2. Serum $\alpha$-Toc concentration at $4 \mathrm{wk}$ was significantly higher $(P<0.05)$ than those at other weeks. Liver injury was assessed by the activities of plasma aspartate transaminase and $\gamma$-glutamyl transpeptidase (liver function markers), which gradually increased $(P<0.05)$ from -1 to $1 \mathrm{wk}$ relative to parturition and remained at higher levels until 4 wk relative to parturition. Plasma fatty acid and ketone body concentrations and hepatic TG contents were measured as indicators of NEB. The plasma fatty acid concentrations rapidly increased $(P$ $<0.05)$ at parturition and remained high for a week. The plasma ketone body concentration in the first week of lactation significantly increased $(P<0.05)$ compared with the levels during the antepartum period. No time effect on the hepatic TG content was detected during the peripartum period. However, after calving, the liver accumulated TG, increasing the mean levels about 30fold at 4 wk relative to parturition compared with those during the precalving.

\section{$\alpha$-Toc Transport and $\alpha-T o c-R e l a t e d$ Gene Expressions in the Mammary Gland (Exp. 3)}

The concentrations of $\alpha$-Toc in colostrum were significantly greater $(P<0.05)$ than those in precolostrum (samples were collected at wk -1 relative to parturition) and mature milk (Figure 6). Arterial concentration, AVD, and mammary extraction ratios of $\alpha$-Toc are shown in Table 3. Arterial concentration of $\alpha$-Toc gradually decreased $(P<0.05)$ and reached a nadir just after calving. The extraction ratio and AVD did not vary significantly and their values remained negative throughout the experiment. The changes in mRNA expression of $\alpha$-Toc-related genes in mammary gland tissue are shown in Figure 7. The AFM transcript in mammary gland tissue was not detected (data not shown). The expression level of TTPA mRNA at $6 \mathrm{wk}$ relative to parturition was significantly downregulated $(P<0.05)$ by about $60 \%$ as compared with that at 0 wk relative to parturition. The expressions of $S E C 14 L 2$ and SRB1 mRNA gradually decreased; the values at 0 wk relative to parturition were lower $(P<0.05)$ than 


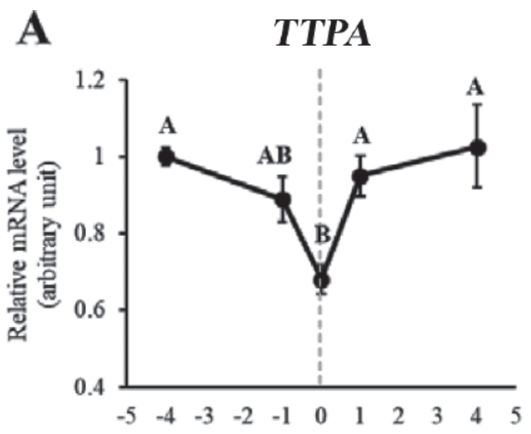

CYP4F2

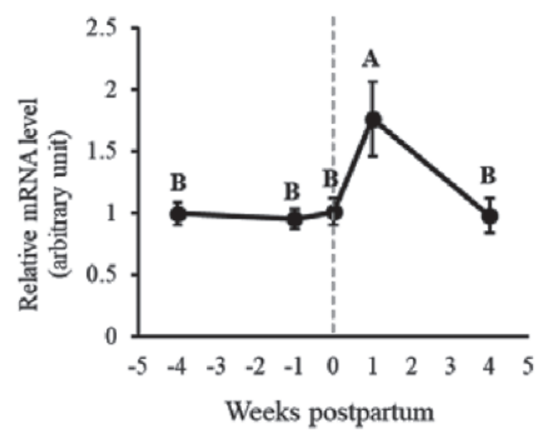

B

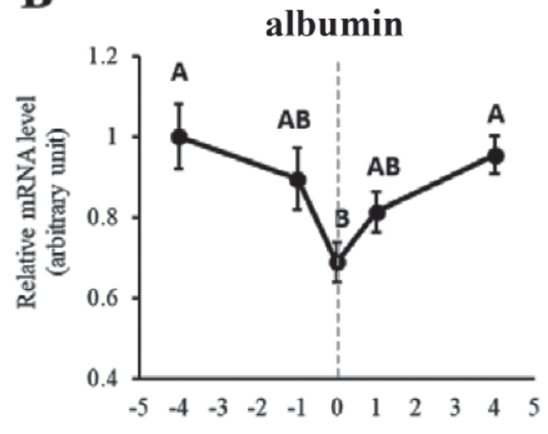

Weeks postpartum
XBP1

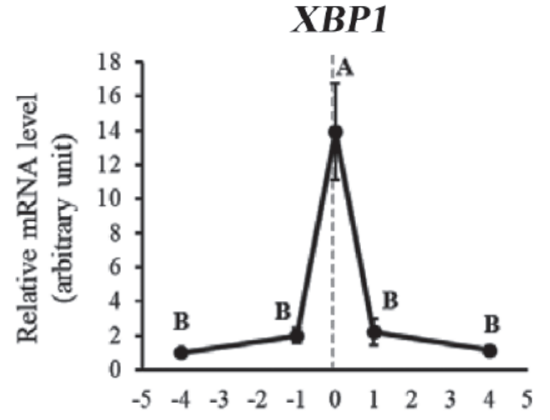

SEC14L2

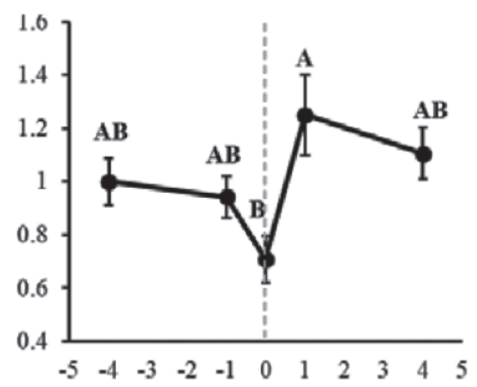

SRB1

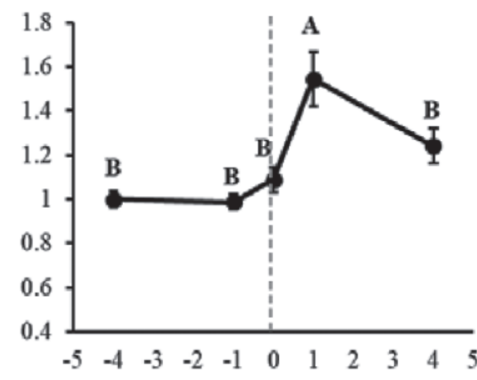

Weeks postpartum
AFM

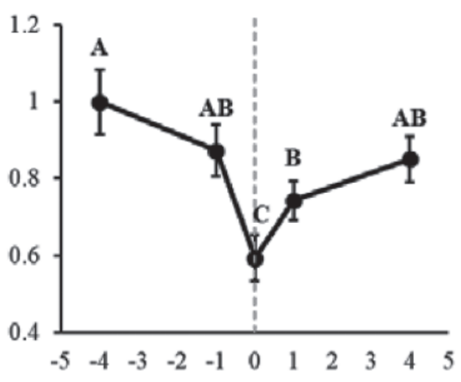

ABCA1

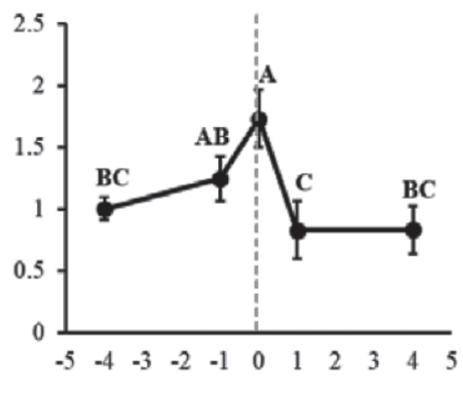

Weeks postpartum
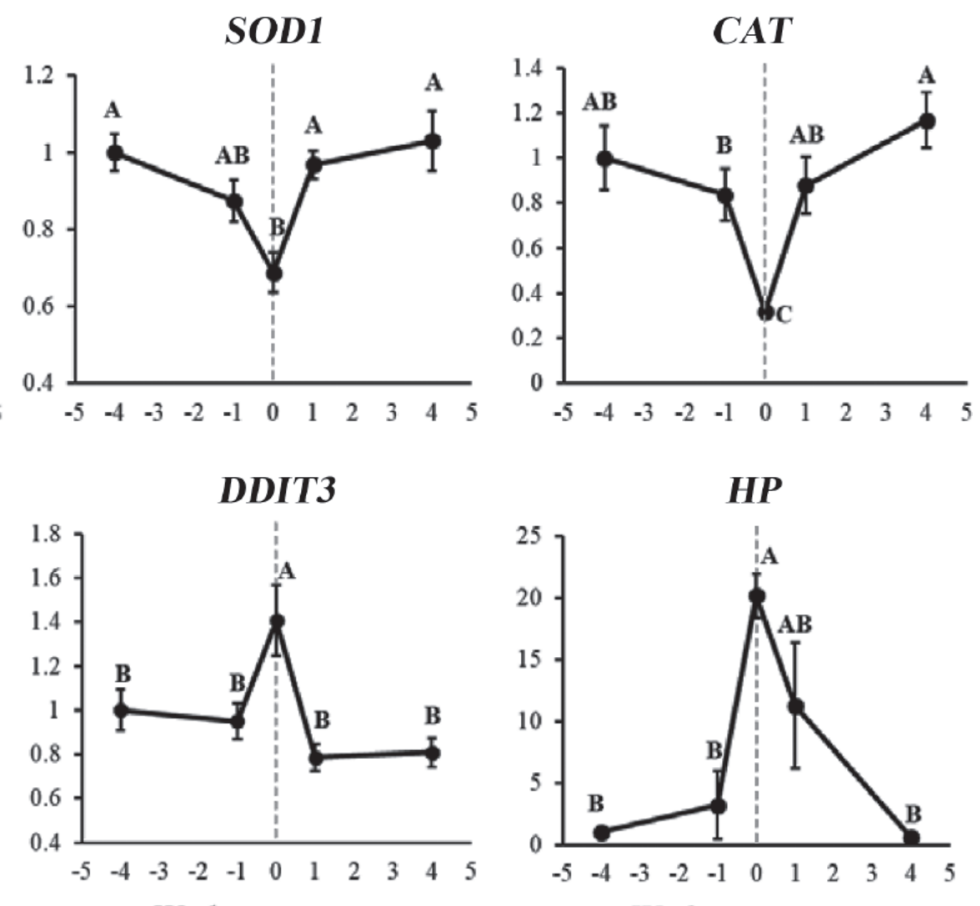

Weeks postpartum

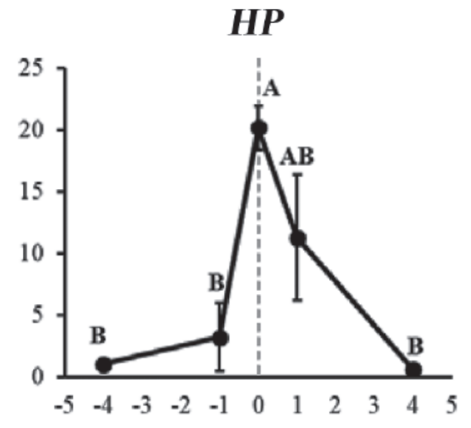

Weeks postpartum

Figure 5. Hepatic mRNA expression levels in peripartum dairy cows. (A) The mRNA of $\alpha$-tocopherol-related molecules $[\alpha$-tocopherol transfer protein $(T T P A)$; tocopherol-associated protein (SEC14L2); afamin $(A F M)$; cytochrome P450 family 4, subfamily F, polypeptide 2 (CYP4F2); scavenger receptor class B, Type I (SRB1); and ATP-binding cassette transporter A1 $(A B C A 1)]$. (B) The mRNA of albumin, antioxidant enzymes [superoxide dismutase-1 $(S O D 1)$ and catalase $(C A T)$ ], endoplasmic reticulum stress-induced unfolded protein response markers [spliced form of X-box binding protein 1 (XBP1) and C/EBP-homologous protein 10 (DDIT3)], and haptoglobin (HP). Messenger RNA expression levels of all genes were normalized by arithmetic mean of the ribosomal protein S9 and $\beta$-actin mRNA expressions as multiple housekeeping genes. Data are expressed as means $\pm \mathrm{SE}(\mathrm{n}=7)$. Different capital letters $(\mathrm{A}-\mathrm{C})$ indicate significant difference according to Tukey-Kramer test $(P<$ $0.05)$. 
Table 2. Changes in serum $\alpha$-tocopherol, plasma metabolic parameters, and hepatic triglyceride (TG) content in dairy cows during the peripartum period in experiment $2^{1}$

\begin{tabular}{|c|c|c|c|c|c|c|c|}
\hline \multirow[b]{2}{*}{ Item } & \multicolumn{5}{|c|}{ Week relative to parturition } & \multirow[b]{2}{*}{ SEM } & \multirow[b]{2}{*}{$P$-value } \\
\hline & -4 & -1 & 0 & 1 & 4 & & \\
\hline Plasma $\gamma \mathrm{GTP}(\mathrm{IU} / \mathrm{L})$ & $19.7^{\mathrm{bc}}$ & $18.6^{\mathrm{c}}$ & $23.4^{\mathrm{abc}}$ & $26.1^{\mathrm{a}}$ & $25.4^{\mathrm{a}}$ & 1.1 & $<0.01$ \\
\hline Plasma GOT $(\mathrm{IU} / \mathrm{L})$ & $59.0^{\mathrm{ab}}$ & $54.4^{\mathrm{b}}$ & $60.6^{\mathrm{ab}}$ & $74.9^{\mathrm{a}}$ & $74.4^{\mathrm{ab}}$ & 2.5 & $<0.05$ \\
\hline Plasma FA $(\mathrm{mEq} / \mathrm{L})$ & $0.18^{\mathrm{b}}$ & $0.27^{\mathrm{b}}$ & $0.86^{\mathrm{a}}$ & $1.01^{\mathrm{a}}$ & $0.41^{\mathrm{b}}$ & 0.1 & $<0.01$ \\
\hline Plasma ketone body $(\mu M)$ & $396.0^{\mathrm{b}}$ & $385.4^{\mathrm{b}}$ & $521.6^{\mathrm{ab}}$ & $937.0^{\mathrm{a}}$ & $737.7^{\mathrm{ab}}$ & 60.9 & $<0.01$ \\
\hline
\end{tabular}

${ }^{\mathrm{a}-\mathrm{c}}$ Within a row, significant differences $(P<0.05)$ among the values at 5 time points $(\mathrm{n}=7)$.

${ }^{1} \gamma \mathrm{GTP}=\gamma$-glutamyl transpeptidase; GOT $=$ aspartate transaminase; $\mathrm{FA}=$ fatty acids; ketone body $=$ combining acetoacetate and $\mathrm{BHB}$.

those at -8 wk relative to parturition and represented the lowest level among sampling points. These levels recovered $(P<0.05)$ at 6 wk relative to parturition. The expression of $C Y P 4 F 2$ mRNA at 6 wk relative to parturition was significantly greater $(P<0.05)$ than at other times of the experimental period.

The raw data of cross-experiment comparisons is presented in the supplemental data because we could not carry out the same conditions and sampling among 3 experiments in this study. The DMI and $\alpha$-Toc intake in Exp. 2 were lower than those in Exp. 1 (Supplemental Figure S2; https://doi.org/10.3168/jds.2017-13630). Although we did not record DMI in Exp. 3, the milk yield in Exp. 3 was lower than that in Exp. 1 and 2 (Supplemental Figure S3; https://doi.org/10.3168/jds .2017-13630). The colostrum $\alpha$-Toc concentrations in Exp. 1 were lower than those in Exp. 2 and 3 (Supplemental Table S2; https://doi.org/10.3168/jds.2017 -13630). The serum $\alpha$-Toc concentration at -4 wk in Exp. 2 was less than $200 \mu \mathrm{g} / \mathrm{dL}$; however, each serum $\alpha$-Toc concentration at $-1,0$, and 4 wk was equal in the 3 experiments (Supplemental Table S3; https://doi .org/10.3168/jds.2017-13630).

\section{DISCUSSION}

We present the first evidence of the downregulation of expression of TTPA, SEC14L2, and AFM mRNA in the liver at calving. Furthermore, the present study is the first to report the mRNA expression of TTPA, SEC14L2, and CYP4F2 in bovine mammary glands, and the changes in TTPA, SEC14L2, SRB1, and $C Y$ P4F2 mRNA expressions around calving. These results suggest that $\alpha$-Toc-related gene expression involved in specific $\alpha$-Toc transfer and metabolism in the liver and mammary gland of dairy cows might alter from late pregnancy to early lactation.

Blood concentrations of $\alpha$-Toc in dairy cows gradually decrease throughout prepartum, reaching a nadir at calving, and remaining at lower levels during early lactation but increasing thereafter (Kumagai and Chaipan, 2004; Meglia et al., 2006). In the present study (Exp. 1), we confirmed the same trends in the change of serum $\alpha$-Toc concentrations and the onset of severe hypovitaminosis E (less than $200 \mu \mathrm{g} / \mathrm{dL}$ ) around calving when based on the $300 \mu \mathrm{g} / \mathrm{dL}$ cutoff for adequacy as suggested by Weiss (1998). To determine whether the decreasing serum $\alpha$-Toc concentrations reflect the decline in $\alpha$-Toc intake due to decreasing DMI around calving, we compared the rate of change between the serum $\alpha$-Toc concentrations and $\alpha$-Toc intake using monitoring data. In the prepartum period, the decrease

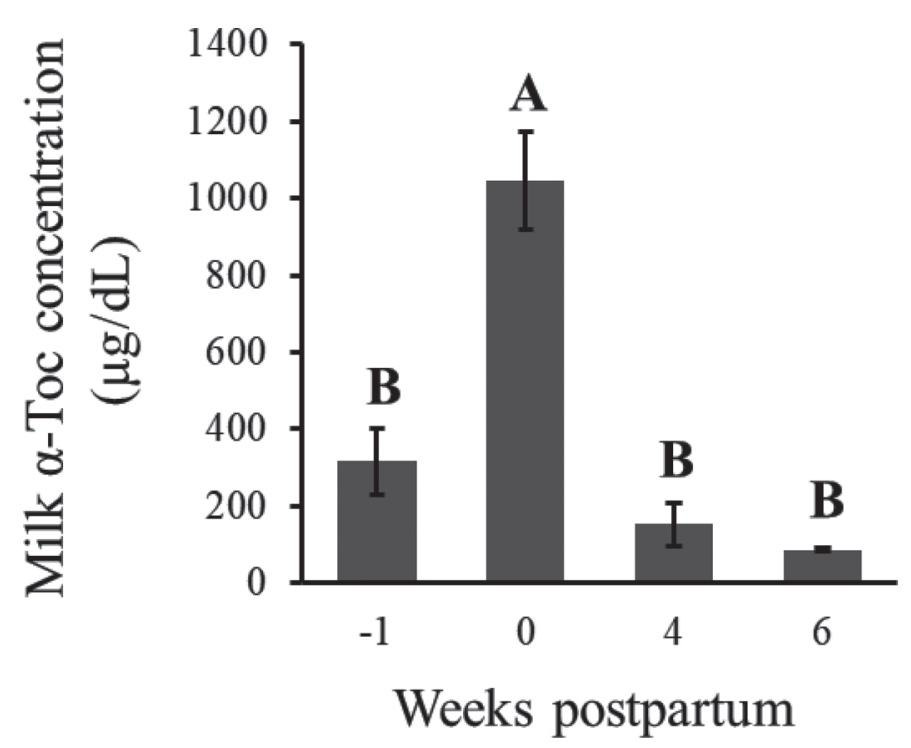

Figure 6. $\alpha$-Tocopherol $(\alpha-$ Toc) concentrations in milk of peripartum dairy cows. Individual milk samples were collected at wk -1 (precolostrum; $-8.7 \pm 2.2 \mathrm{~d}$ ), 0 (colostrum; within $12 \mathrm{~h}$ from calving), $4(25 \mathrm{~d})$, and $6(40 \mathrm{~d})$ relative to parturition. Data are expressed as means $\pm \operatorname{SE}(n=10)$. Different capital letters $(A, B)$ indicate significant difference according to Tukey-Kramer test $(P<0.05)$. We could not measure milk fat concentration in the precolostrum sample using infrared spectroscopy (Milko-Scan 133B, Foss Electric, Hillerød, Denmark) because the precolostrum was a viscous secretion; therefore, we showed the data of milk $\alpha$-Toc concentrations $(\mu \mathrm{g} / \mathrm{dL})$. 
Table 3. Arterial $\alpha$-tocopherol concentration, arterial-venous differences (AVD), and extraction ratio of $\alpha$-tocopherol during the peripartum period in experiment 3

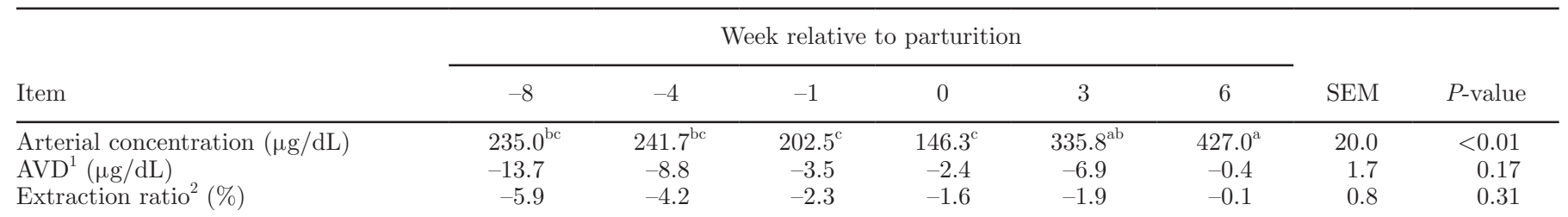

${ }^{a-c}$ Significant differences $(P<0.05)$ among the values at 6 time points $(\mathrm{n}=5)$.

${ }^{1} \mathrm{AVD}=$ serum concentration difference between the coccygeal artery and milk vein.

${ }^{2}$ Extraction ratio $=($ AVD $\times 100) /$ arterial concentration.

in $\alpha$-Toc rates was similar between the intake and blood levels, but after calving the increase in serum $\alpha$-Toc concentrations was delayed compared with the recovery of $\alpha$-Toc intake. These results suggested that decreased $\alpha$-Toc intake levels might be one of the causes that strongly influence the decrease in serum $\alpha$-Toc concentrations until precalving, but not the only influencer during postcalving. Blood concentration of HDL, a major lipoprotein carrier of $\alpha$-Toc in plasma in dairy cattle (Herdt and Smith, 1996; Higuchi et al., 2013), gradually decreases throughout prepartum, reaching a nadir at calving and increasing thereafter. Based on the monitoring of the changes in blood $\alpha$-Toc-to-HDL ratio from -2 to 2 wk relative to parturition, we confirmed that, after calving, the serum $\alpha$-Toc concentration was below the saturation level of the HDL transport capacity for $\alpha$-Toc as compared with that during precalving. This result suggested that remaining at lower serum $\alpha$-Toc concentrations after calving might not result in lower HDL concentrations. Based on the results in Exp. 1 , it appeared that other causes might determine the lower serum $\alpha$-Toc concentrations during first week after calving besides changes in the levels of $\alpha$-Toc intake and blood HDL concentrations. We speculated that the major reason of the lower serum $\alpha$-Toc concentration throughout the prepartum period in Exp. 2 compared with that in Exp. 1 was the lower DMI during this period. However, we could not confirm the direct effect of liver biopsy on the DMI of cows in Exp. 2. According to the comparisons of serum $\alpha$-Toc concentrations across the 3 experiments, the amount of $\alpha$-Toc intake in Exp. 3 might be similar as that in Exp. 1, although we did not measure the DMI and $\alpha$-Toc content in diet in Exp. 3.

Interestingly, the liver tissue biopsy (in Exp. 2) demonstrated that mRNA expression of hepatic $\alpha$-Toc-specific binding proteins, $\alpha$-tocopherol transfer protein, tocopherol-associated protein, and afamin, were strongly downregulated at calving. $\alpha$-Tocopherol transfer protein is known to play a crucial role in the transfer of dietary $\alpha$-Toc from the liver into the cir- culation (Ouahchi et al., 1995; Qian et al., 2005), and afamin, a member of the albumin family, is another potential candidate molecule for transport of $\alpha$-Toc to the plasma and extravascular fluids (Voegele et al., 2002). $\alpha$-Tocopherol transfer protein has high specificity for 2R-isomers (RRR, RRS, RSS, and RSR) of $\alpha$-Toc (Lim and Traber, 2007), of which the one with natural stereochemistry $(R R R)$ is by far the most predominant form in blood and milk of periparturient dairy cows, irrespective of dietary $\alpha$-Toc such as natural or synthetic isomers (Meglia et al., 2006). Takenaka et al. (2007) reported that hepatic expression of TTPA mRNA is suppressed by acute liver injury in rats. In Exp. 2, the expression of albumin mRNA, the most basal hepatic function, was also downregulated, and the hepatic ER stress-induced UPR and acute-phase response occurred at calving. Furthermore, our monitoring in Exp. 1 indicates that systemic physiological and oxidative stress also occurred around calving. It is likely that the inflammation and development of fatty liver can induce the hepatic ER stress in peripartum dairy cows (Gessner et al., 2014). After the first week postpartum, when the downregulation of mRNA expression of TTPA, $A F M$, and albumin recovered, the elevated UPR markers and the haptoglobin mRNA expression decreased although aggravation of NEB induced the development of a mild fatty liver ( 1 to $5 \%$ liver TG; Bobe et al., 2004). In contrast, the hepatic $A B C A 1$ mRNA expression was upregulated after calving. Shichiri et al. (2010) reported that ABCA1, along with TTPA, mediates the process of hepatic $\alpha$-Toc secretion; TTPA transports $\alpha$-Toc to the plasma membrane, where it is picked up by ABCA1 and excreted from the hepatocyte. However, increased $A B C A 1 \mathrm{mRNA}$ expression after calving could not contribute to the increase of hepatic $\alpha$-Toc secretion at that time because TTPA mRNA expression was downregulated. These results suggested that dietary $\alpha$-Toc, absorbed by the intestine, is transferred from liver into the bloodstream, which might be suppressed in the first days after calving because of temporal downregulation of TTPA and AFM by induc- 
TTPA

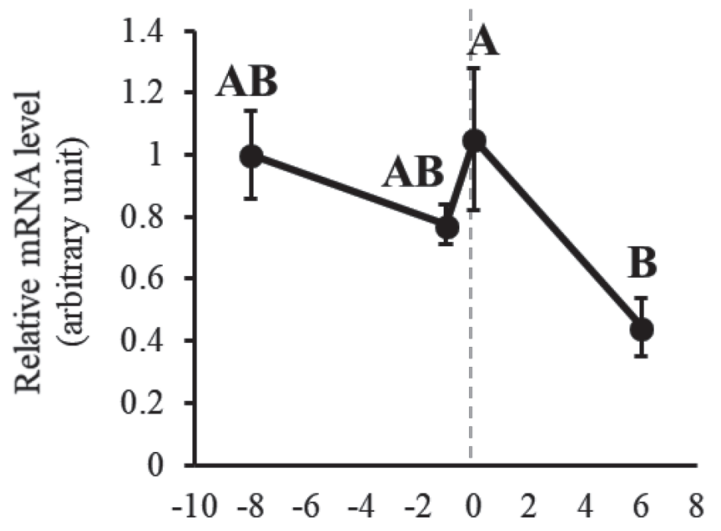

CYP4F2

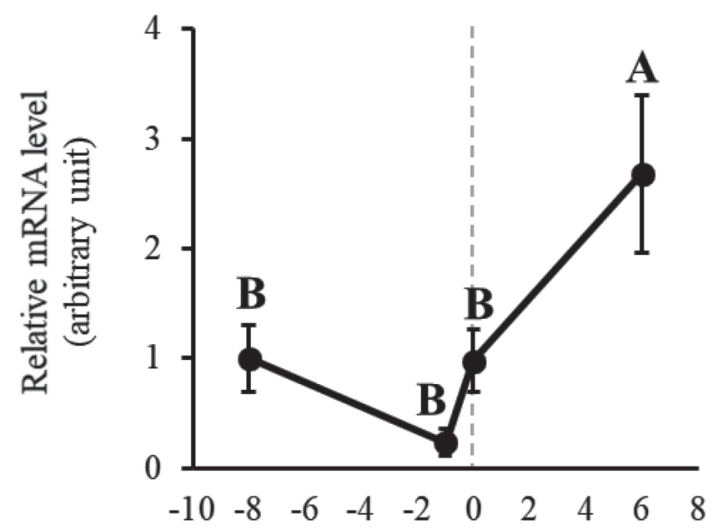

ABCA1

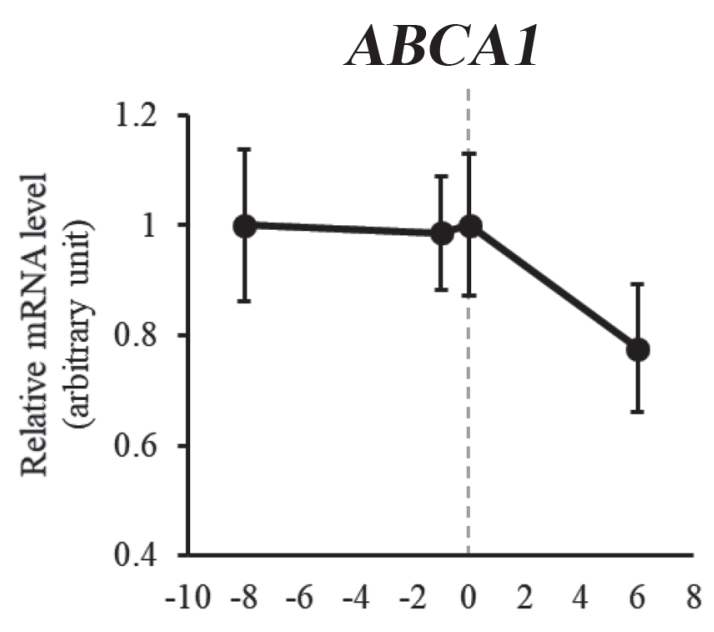

SEC14L2

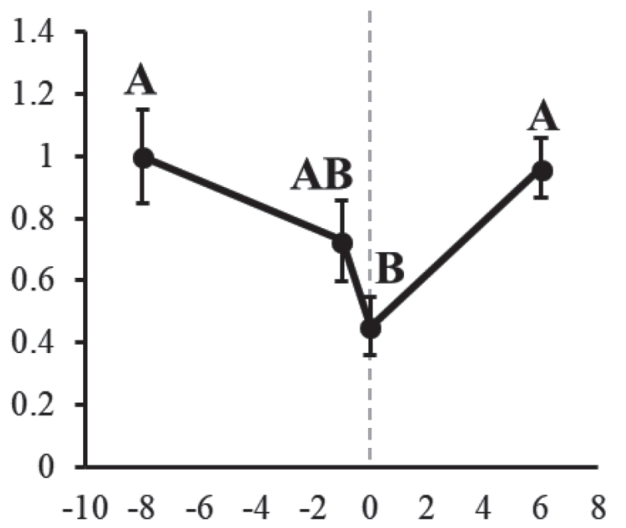

SRB1

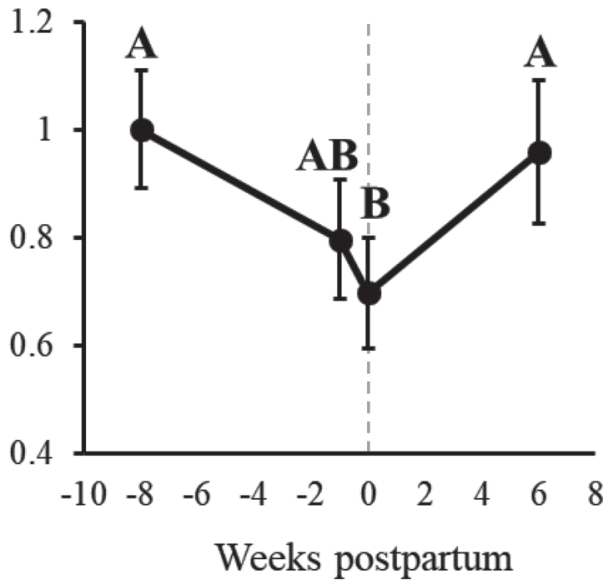

Weeks postpartum

Figure 7. Expression levels of $\alpha$-tocopherol-related genes in mammary gland tissues of peripartum dairy cows. Messenger RNA expression levels of all molecules were normalized by arithmetic mean of the ribosomal protein S9 and $\beta$-actin mRNA expressions as multiple housekeeping genes. Data are expressed as means $\pm \mathrm{SE}(\mathrm{n}=10)$. Different capital letters $(\mathrm{A}, \mathrm{B})$ indicate significant difference according to Tukey-Kramer test $(P<0.05) . T T P A=\alpha$-tocopherol transfer protein; SEC14L2 = tocopherol-associated protein; CYP4F2= cytochrome P450 family 4, subfamily F, polypeptide $2 ; S R B 1=$ scavenger receptor class B, Type I; $A B C A 1=$ ATP-binding cassette transporter A1. 
ing stress on hepatic function along with parturitioninduced inflammation and physiological stress. After 1 wk relative to parturition, $S R B 1$, which mediates the cellular $\alpha$-Toc uptake (Mardones et al., 2002), showed increases in mRNA expression level; this change might facilitate hepatic $\alpha$-Toc uptake from the circulation. However, CYP 4F2, which catalyzes the first step in the pathway of vitamin E metabolism (Sontag and Parker, 2002), showed increases in mRNA expression level at the same time. $\alpha$-Tocopherol imported via SRB1 might be metabolized in greater amounts by CYP4F2 after 1 wk relative to parturition. These changes in the hepatic expression of $\alpha$-Toc-related genes might be associated with maintaining lower serum $\alpha$-Toc concentrations during first week after calving. In Exp. 1, we confirmed that the increase in systemic oxidative stress around calving coincided roughly with decreasing blood $\alpha$-Toc concentration. Furthermore, mRNA expression of the major antioxidative enzymes, superoxide dismutase-1 and catalase, in the liver was markedly downregulated at calving in Exp. 2. Because $\alpha$-Toc is considered an important antioxidant, these results suggest that both systemic and hepatic antioxidative/oxidative balance may be low around calving. We analyzed only the changes in mRNA expression levels; further studies are needed to investigate hepatic protein expression of $\alpha$-Toc-related molecules and antioxidant enzyme activities in peripartum dairy cows.

It was reported that $\alpha$-Toc concentration in colostrum was about 5 to 8 fold higher than that in mature milk in multiparous dairy cows (Hidiroglou, 1989; Kumagai and Chaipan, 2004; Calderón et al., 2007). $\alpha$-Tocopherol is a lipid-soluble micronutrient and its concentration is strongly affected by the level of milk fat. In the present study, the content of milk fat in colostrum was also higher than that in mature milk in dairy cows; however, the $\alpha$-Toc concentrations in colostrum, which were normalized by the milk fat value ( $\mu \mathrm{g}$ of $\alpha$-Toc/g of milk fat), were about 5 to 8 fold greater than those in mature milk. Therefore, we attempted to confirm the active $\alpha$-Toc transfer from blood into colostrum by the AVD method (Thivierge et al., 1998; Astuti et al., $2015)$, but the changes in the extraction ratio of $\alpha$-Toc around the time of calving were masked due to a high variability (SEM range $\pm 0.8 \%$ ). Previous reports have estimated the efficiency of $\alpha$-Toc transfer from blood to milk at $400 \mathrm{~L}$ of plasma $/ \mathrm{kg}$ of milk produced from the blood flow through the mammary gland (Linzell, 1974; Delamaire and Guinard-Flament, 2006). Using our data on serum and milk $\alpha$-Toc concentrations, milk yield, and assumed colostrum production of at least $10 \mathrm{~kg}$, we calculated the estimated mammary extraction ratio of $\alpha$-Toc after calving (colostrum) and at 6 wk lactation (mature milk) at 1.3 and $0.05 \%$, respectively. Calderón et al. (2007) proposed that the mean rates of $\alpha$-Toc transfer efficiencies in midlactation cows were $0.02 \%$. These estimations suggest that the $\alpha$-Toc uptake during colostrum production might be more than 20 fold greater than that in mature milk production. Furthermore, $\alpha$-Toc was not accumulated in precolostrum (at 1 wk before parturition); therefore, we hypothesized that the high $\alpha$-Toc concentration in colostrum might be caused by the presence of a mechanism that temporarily augments a specific $\alpha$-Toc transfer from the blood to colostrum across the mammary gland at calving, which might be a mechanism contributing to a lower serum $\alpha$-Toc concentration at calving. To test the possibility of presence of this mechanism, we measured the mRNA expression levels of $\alpha$-Toc-related genes in biopsied mammary gland tissues.

The proteins scavenger receptor class B, Type I and ATP-binding cassette transporter A1 play very important roles in cholesterol transport, milk fat globule synthesis, and secretion of milk fat globules in the mammary gland (Ontsouka and Albrecht, 2014). These proteins might also contribute to the transfer of $\alpha$-Toc from blood into colostrum or mature milk. We hypothesized that, for an $\alpha$-Toc-rich colostrum production, the expression of SRB1 mRNA should be upregulated at calving to actively transfer $\alpha$-Toc with a lipoprotein-cholesterol ester from blood into colostrum through mammary epithelial cells. However, contrary to our hypothesis, the mRNA expression of $S R B 1$ in mammary gland tissue was downregulated at calving. In various mice tissues, the $\alpha$-Toc uptake in tissues occurs via SRB1-dependent and -independent pathways (Mardones et al., 2002). Taken together, these observations suggest that the $\alpha$-Toc uptake in bovine mammary glands at calving time might be mediated by $S R B 1$-independent pathways. The $A B C A 1 \mathrm{mRNA}$ and protein levels in bovine mammary glands were higher during the dry off period than during the lactation period (Farke et al., 2008; Mani et al., 2011). Similarly, we observed lower $A B C A 1 \mathrm{mRNA}$ levels during the lactation period, although the expression around calving time was stable. Mani et al. (2011) confirmed that the subcellular distribution of ABCA1 changed throughout the pregnancy-lactation cycle and that ABCA1 was present in the membranes of milk fat globules and thus isolated from fresh mature milk. It was reported that apolipoprotein A-1, the key acceptor of cholesterol and $\alpha$-Toc efflux by ABCA1, was present in the membranes of milk-fat globules and that the apolipoprotein A-1 protein level was significantly higher in the membrane of milk fat globules prepared from colostrum than from mature milk (Reinhardt and Lippolis, 2008). These results suggested that ATP-binding cassette transporter A1 protein molecules localized in the basal and apical 
membranes, as well as in the cytoplasm of mammary epithelial cells, might mediate the transfer of $\alpha$-Toc. To the best of our knowledge, this is the first report on the expression of TTPA, SEC14L2, and CYP4F2 mRNA in bovine mammary gland tissue and the changes in the expression of their mRNA during peripartum. Of particular interest were the differences in the mRNA levels of 2 intracellular $\alpha$-Toc-specific binding proteins, $\alpha$-tocopherol transfer protein and tocopherol-associated protein. Gene expressions of these 2 proteins showed opposite trends, the expression levels of TTPA mRNA peaked and SEC14L2 mRNA reached a nadir at calving. These results suggest that the changes in TTPAto-SEC14L2 mRNA expression ratios, which are due to intracellular $\alpha$-Toc-specific binding patterns, might regulate the $\alpha$-Toc transfer to colostrum. Higher expression levels of CYP4F2 might catalyze more $\alpha$-Toc in lactating mammary gland tissues as compared with the prepartum period, although the serum $\alpha$-Toc concentration during lactation was higher than that in the prepartum period. These results suggest the possibility of the presence of molecular mechanisms, including the transfer of $\alpha$-Toc from blood to colostrum and milk, which might be regulated by $\alpha$-Toc-related genes expressed in mammary gland tissues. In the present study, we measured milk $\alpha$-Toc concentrations using a whole milk sample. Therefore, the milk $\alpha$-Toc concentrations, especially colostrum, might include the $\alpha$-Toc in somatic cells. Further studies that carry out high-precision measurement of $\alpha$-Toc levels transferred directly from plasma into colostrum, excluding somatic cells, and investigate the protein expression and localization of $\alpha$-Toc-related molecules in the mammary gland of peripartum dairy cows are needed.

\section{CONCLUSIONS}

In Exp. 1, we confirmed that the serum $\alpha$-Toc concentrations declined gradually with decreasing $\alpha$-Toc intake and plasma HDL concentrations toward calving. However, in the early lactation period after calving, the serum $\alpha$-Toc concentrations remained at lower levels in spite of the recovery of $\alpha$-Toc intake levels and plasma HDL concentrations. Therefore, we expected that other mechanisms were present for maintaining lower serum $\alpha$-Toc concentrations during first week after calving. In Exp. 2, stress on hepatic function might have been induced with parturition, leading to the inhibition or downregulation of the expression of TTPA and AFM mRNA in the liver, which might have disrupted $\alpha$-Toc transport into the circulation. Furthermore, we are first to report the expression of TTPA, SEC14L2, and $C Y P$ 4F2 mRNA in bovine mammary gland tissue and the changes in the expression of their mRNA during peripartum, as found in Exp. 3. This result indicated that the expression of $\alpha$-Toc-related genes in the mammary gland might contribute to the molecular mechanism that augments the temporary specific $\alpha$-Toc transfer from the blood to colostrum. In conclusion, these results suggest that the expression of $\alpha$-Toc-related genes involved in specific $\alpha$-Toc transfer and metabolism in the liver and mammary gland are altered around calving, and these changes in the expression of $\alpha$-Toc-related genes might be associated with lower serum $\alpha$-Toc concentrations during first week after calving. Further studies investigating the effects of nutritional vitamin E challenge on the expression of $\alpha$-Toc-related genes in the liver and mammary gland are needed to provide fundamental information for the causes of hypovitaminosis $\mathrm{E}$ around calving in dairy cows.

\section{ACKNOWLEDGMENTS}

We are grateful to the staff of the Grassland Research Support Center, Institute of Livestock and Grassland Science, National Agriculture and Food Research Organization (NARO), for animal supplies and management. We sincerely appreciate the efforts of Reiko Kobayashi and Ayumi Sueda (Institute of Livestock and Grassland Science, NARO) for their skilled technical assistance in sampling and performing measurements. The Research Information Technology Center (Agriculture, Forestry and Fisheries Research, MAFF, Tsukuba, Japan) assisted in application of SAS Add-In 7.1 for Microsoft Office. This work was supported by the Japan Society for the Promotion of Science (Tokyo) Grants-in-Aid for Scientific Research, Grant Numbers 25871102 and $15 \mathrm{~K} 21620$.

\section{REFERENCES}

AOAC International. 2000. Official Methods of Analysis of AOAC International, 17th ed. AOAC International, Gaithersburg, MD.

Astuti, A., T. Obitsu, T. Sugino, K. Taniguchi, M. Okita, and Y. Kurokawa. 2015. Milk production, plasma metabolite profiles and mammary arterial-venous differences of milk precursors in early lactation cows milked at different frequencies by an automatic milking system. Anim. Sci. J. 86:499-507. https://doi.org/10 .1111 /asj.12332.

Bobe, G., J. W. Young, and D. C. Beitz. 2004. Invited review: Pathology, etiology, prevention, and treatment of fatty liver in dairy cows. J. Dairy Sci. 87:3105-3124. https://doi.org/10.3168/jds .S0022-0302(04)73446-3.

Calderón, F., B. Chauveau-Duriot, B. Martin, B. Graulet, M. Doreau, and P. Nozière. 2007. Variations in carotenoids, vitamins A and $\mathrm{E}$, and color in cow's plasma and milk during late pregnancy and the first three months of lactation. J. Dairy Sci. 90:2335-2346. https://doi.org/10.3168/jds.2006-630.

Delamaire, E., and J. Guinard-Flament. 2006. Longer milking intervals alter mammary epithelial permeability and the udder's ability 
to extract nutrients. J. Dairy Sci. 89:2007-2016. https://doi.org/ 10.3168/jds.S0022-0302(06)72268-8.

Farke, C., H. H. Meyer, R. M. Bruckmaier, and C. Albrecht. 2008. Differential expression of $\mathrm{ABC}$ transporters and their regulatory genes during lactation and dry period in bovine mammary tissue. J. Dairy Res. 75:406-414. https://doi.org/10.1017/ S002202990800335X.

Farr, V. C., K. Stelwagen, L. R. Cate, A. J. Molenaar, T. B. McFadden, and S. R. Davis. 1996. An improved method for the routine biopsy of bovine mammary tissue. J. Dairy Sci. 79:543-549. https://doi.org/10.3168/jds.S0022-0302(96)76398-1.

Gessner, D. K., G. Schlegel, R. Ringseis, F. J. Schwarz, and K. Eder. 2014. Up-regulation of endoplasmic reticulum stress induced genes of the unfolded protein response in the liver of periparturient dairy cows. BMC Vet. Res. 10:46. https://doi.org/10.1186/1746-6148-10 -46 .

Goff, J. P., K. Kimura, and R. L. Horst. 2002. Effect of mastectomy on milk fever, energy, and vitamins A, E, and beta-carotene status at parturition. J. Dairy Sci. 85:1427-1436. https://doi.org/10.3168/ jds.S0022-0302(02)74210-0.

Goff, J. P., and J. R. Stabel. 1990. Decreased plasma retinol, $\alpha$-tocopherol, and zinc concentration during the periparturient period: Effect of milk fever. J. Dairy Sci. 73:3195-3199. https://doi .org/10.3168/jds.S0022-0302(90)79010-8.

Haga, S., H. Ishizaki, M. Nakano, S. Nakao, K. Hirano, Y. Yamamoto, M. Kitagawa, H. Sasaki, and Y. Kariya. 2014. Increase in plasma total antioxidant capacity of grazing Japanese Black heifers and cows in forestland in Japan. Anim. Sci. J. 85:135-142. https://doi .org/10.1111/asj.12102

Haga, S., M. Nakano, H. Ishizaki, S. G. Roh, and K. Katoh. 2015 Expression of $\alpha$-tocopherol-associated genes and $\alpha$-tocopherol accumulation in Japanese Black (Wagyu) calves with and without $\alpha$-tocopherol supplementation. J. Anim. Sci. 93:4048-4057. https://doi.org/10.2527/jas.2015-9106.

Herdt, T. H., and J. C. Smith. 1996. Blood-lipid and lactation-stage factors affecting serum vitamin $\mathrm{E}$ concentrations and vitamin $\mathrm{E}$ cholesterol ratios in dairy cattle. J. Vet. Diagn. Invest. 8:228-232. https://doi.org/10.1177/104063879600800213.

Hidiroglou, M. 1989. Mammary transfer of vitamin E in dairy cows. J. Dairy Sci. 72:1067-1071. https://doi.org/10.3168/jds.S0022 -0302(89)79204-3.

Higuchi, H., E. Ito, H. Iwano, S. Oikawa, and H. Nagahata. 2013. Effects of vitamin E supplementation on cellular $\alpha$-tocopherol concentrations of neutrophils in Holstein calves. Can. J. Vet. Res. $77: 120-125$.

Ingvartsen, K. L., R. J. Dewhurst, and N. C. Friggens. 2003. On the relationship between lactational performance and health: Is it yield or metabolic imbalance that cause production diseases in dairy cattle? A position paper. Livest. Prod. Sci. 83:277-308. https:// doi.org/10.1016/S0301-6226(03)00110-6.

Janovick-Guretzky, N. A., H. M. Dann, D. B. Carlson, M. R. Murphy, J. J. Loor, and J. K. Drackley. 2007. Housekeeping gene expression in bovine liver is affected by physiological state, feed intake, and dietary treatment. J. Dairy Sci. 90:2246-2252. https://doi.org/10 $.3168 /$ jds.2006-640.

Jensen, S. K., and K. N. Nielsen. 1996. Tocopherols, retinol, $\beta$-carotene and fatty acids in fat globule membrane and fat globule core in cows' milk. J. Dairy Res. 63:565-574. https://doi.org/10.1017/ S0022029900032106.

Kumagai, H., and Y. Chaipan. 2004. Changes of vitamin E status of periparturient dairy cows and newborn calves. Anim. Sci. J. 75:541-547. https://doi.org/10.1111/j.1740-0929.2004.00225.x.

Lim, Y., and M. G. Traber. 2007. Alpha-tocopherol transfer protein $(\alpha-$ TTP): Insights from alpha-tocopherol transfer protein knockout mice. Nutr. Res. Pract. 1:247-253. https://doi.org/10.4162/ nrp.2007.1.4.247.

Linzell, J. L. 1974. Mammary blood flow and methods of identifying and measuring precursors of milk. Pages $143-225$ in Lactation: A Comprehensive Treatise. Vol. 1. B. L. Larson and V. R. Smith, ed. Academic Press, New York, NY.
Mani, O., M. Körner, C. E. Ontsouka, M. T. Sorensen, K. Sejrsen, R. M. Bruckmaier, and C. Albrecht. 2011. Identification of ABCA1 and ABCG1 in milk fat globules and mammary cells-Implications for milk cholesterol secretion. J. Dairy Sci. 94:1265-1276. https://doi.org/10.3168/jds.2010-3521.

Mardones, P., P. Strobel, S. Miranda, F. Leighton, V. Quiñones, L. Amigo, J. Rozowski, M. Krieger, and A. Rigotti. 2002. Alphatocopherol metabolism is abnormal in scavenger receptor class $\mathrm{B}$ type I (SR-BI)-deficient mice. J. Nutr. 132:443-449.

Meglia, G. E., S. K. Jensen, C. Lauridsen, and K. Persson Waller. 2006. Alpha-tocopherol concentration and stereoisomer composition in plasma and milk from dairy cows fed natural or synthetic vitamin E around calving. J. Dairy Res. 73:227-234. https://doi .org/10.1017/S0022029906001701.

Miura, M., K. Ogura, T. Sakai, and Y. Igarashi. 1987. Improvement of techniques for liver biopsy in dairy cattle. Nippon Juishikai Zasshi 40:867-870. https://doi.org/10.12935/jvma1951.40.867 (Abstract in English).

NARO (National Agriculture and Food Research Organization). 2006. Japanese Feeding Standard for Dairy Cattle. Japan Livestock Industry Association, Tokyo.

NARO (National Agriculture and Food Research Organization). 2009 Standard Table of Feed Composition in Japan. Japan Livestock Industry Association, Tokyo.

NARO (National Agriculture and Food Research Organization). 2011. The Guideline for the Institute of Livestock and Grassland Science. Japan Livestock Industry Association, Tokyo.

NRC. 2001. Nutrient Requirements of Dairy Cattle. 7th Rev. Ed. Natl. Acad. Press, Washington, DC.

Ontsouka, E. C., and C. Albrecht. 2014. Cholesterol transport and regulation in the mammary gland. J. Mammary Gland Biol. Neoplasia 19:43-58. https://doi.org/10.1007/s10911-014-9316-x.

Ouahchi, K., M. Arita, H. Kayden, F. Hentati, M. Ben Hamida, R. Sokol, H. Arai, K. Inoue, J. L. Mandel, and M. Koenig. 1995. Ataxia with isolated vitamin $\mathrm{E}$ deficiency is caused by mutations in the $\alpha$-tocopherol transfer protein. Nat. Genet. 9:141-145. https://doi .org/10.1038/ng0295-141.

Politis, I., G. Theodorou, A. D. Lampidonis, A. Kominakis, and A. Baldi. 2012. Short communication: Oxidative status and incidence of mastitis relative to blood $\alpha$-tocopherol concentrations in the postpartum period in dairy cows. J. Dairy Sci. 95:7331-7335. https://doi.org/10.3168/jds.2012-5866.

Pontes, G. C., P. L. Monteiro Jr., A. B. Prata, M. M. Guardieiro, D. A. Pinto, G. O. Fernandes, M. C. Wiltbank, J. E. Santos, and R. Sartori. 2015. Effect of injectable vitamin E on incidence of retained fetal membranes and reproductive performance of dairy cows. J. Dairy Sci. 98:2437-2449. https://doi.org/10.3168/jds.2014 -8886 .

Qian, J., S. Morley, K. Wilson, P. Nava, J. Atkinson, and D. Manor. 2005. Intracellular trafficking of vitamin E in hepatocytes: the role of tocopherol transfer protein. J. Lipid Res. 46:2072-2082. https:// doi.org/10.1194/jlr.M500143-JLR200.

Qu, Y., K. Lytle, M. G. Traber, and G. Bobe. 2013. Depleted serum vitamin $\mathrm{E}$ concentrations precede left displaced abomasum in early-lactation dairy cows. J. Dairy Sci. 96:3012-3022. https://doi .org/10.3168/jds.2012-6357.

Reinhardt, T. A., and J. D. Lippolis. 2008. Developmental changes in the milk fat globule membrane proteome during the transition from colostrum to milk. J. Dairy Sci. 91:2307-2318. https://doi .org/10.3168/jds.2007-0952.

Shichiri, M., Y. Takanezawa, D. E. Rotzoll, Y. Yoshida, T. Kokubu, K. Ueda, H. Tamai, and H. Arai. 2010. ATP-binding cassette transporter A1 is involved in hepatic alpha-tocopherol secretion. J. Nutr. Biochem. 21:451-456. https://doi.org/10.1016/j.jnutbio 2009.02.002.

Sontag, T. J., and R. S. Parker. 2002. Cytochrome P450 omega-hydroxylase pathway of tocopherol catabolism. Novel mechanism of regulation of vitamin E status. J. Biol. Chem. 277:25290-25296. https://doi.org/10.1074/jbc.M201466200. 
Takenaka, A., A. Kita, M. Ikeya, H. Arai, and K. Igarashi. 2007. Galactosamine-induced acute liver injury in rats reduces hepatic alpha-tocopherol transfer protein production. J. Nutr. Sci. Vitaminol. (Tokyo) 53:366-371. https://doi.org/10.3177/jnsv.53.366.

Tharwat, M., A. Takamizawa, Y. Z. Hosaka, D. Endoh, and S. Oikawa. 2012. Hepatocyte apoptosis in dairy cattle during the transition period. Can. J. Vet. Res. 76:241-247.

Thivierge, M. C., P. Y. Chouinard, J. Lévesque, V. Girard, J. R. Seoane, and G. J. Brisson. 1998. Effects of buffers on milk fatty acids and mammary arteriovenous differences in dairy cows fed Ca salts of fatty acids. J. Dairy Sci. 81:2001-2010. https://doi.org/10 .3168/jds.S0022-0302(98)75774-1.

Traber, M. G. 2007. Vitamin E regulatory mechanisms. Annu. Rev. Nutr. 27:347-362. https://doi.org/10.1146/annurev.nutr.27.061406 .093819 .

Van Soest, P. J., J. B. Robertson, and B. A. Lewis. 1991. Methods for dietary fiber, neutral detergent fiber, and non-starch polysaccharides in relation to animal nutrition. J. Dairy Sci. 74:3583-3597. https://doi.org/10.3168/jds.S0022-0302(91)78551-2.

Voegele, A. F., L. Jerković, B. Wellenzohn, P. Eller, F. Kronenberg, K. R. Liedl, and H. Dieplinger. 2002. Characterization of the vitamin E-binding properties of human plasma afamin. Biochemistry 41:14532-14538. https://doi.org/10.1021/bi026513v.

Weiss, W. P. 1998. Requirements of fat-soluble vitamins for dairy cows: A review. J. Dairy Sci. 81:2493-2501. https://doi.org/10 .3168/jds.S0022-0302(98)70141-9.

Weiss, W. P., J. S. Hogan, K. L. Smith, and K. H. Hoble. 1990b. Relationships among selenium, vitamin $\mathrm{E}$, and mammary gland health in commercial dairy herds. J. Dairy Sci. 73:381-390. https://doi org/10.3168/jds.S0022-0302(90)78684-5.

Weiss, W. P., J. S. Hogan, D. A. Todhunter, and K. L. Smith. 1997. Effect of vitamin E supplementation in diets with a low concentration of selenium on mammary gland health of dairy cows. J. Dairy Sci. 80:1728-1737. https://doi.org/10.3168/jds.S0022 -0302(97)76105-8

Weiss, W. P., D. A. Todhunter, J. S. Hogan, and K. L. Smith. 1990a. Effect of duration of supplementation of selenium and vitamin $\mathrm{E}$ on periparturient dairy cows. J. Dairy Sci. 73:3187-3194. https:// doi.org/10.3168/jds.S0022-0302(90)79009-1.

Yadav, P., D. D. Singh, M. Mukesh, R. S. Kataria, A. Yadav, A. K. Mohanty, and B. P. Mishra. 2012. Identification of suitable housekeeping genes for expression analysis in mammary epithelial cells of buffalo (Bubalus bubalis) during lactation cycle. Livest. Sci. 147:72-76. https://doi.org/10.1016/j.livsci.2012.04.004.

Yamauchi, J., T. Iwamoto, S. Kida, S. Masushige, K. Yamada, and T. Esashi. 2001. Tocopherol-associated protein is a ligand-dependent transcriptional activator. Biochem. Biophys. Res. Commun. 285:295-299. https://doi.org/10.1006/bbrc. 2001.5162.

Yonezawa, T., S. Yonekura, Y. Kobayashi, A. Hagino, K. Katoh, and Y. Obara. 2004. Effects of long-chain fatty acids on cytosolic triacylglycerol accumulation and lipid droplet formation in primary cultured bovine mammary epithelial cells. J. Dairy Sci. 87:25272534. https://doi.org/10.3168/jds.S0022-0302(04)73377-9. 